[ KLAUDIJA ŠTERMAN IVANČIČ (UR.)

\title{
IZHODIŠČC MERJENJA FINANČNE PISMENOSTI V RAZISKAVI PISA 2012 S PRIMERI NALOG
}

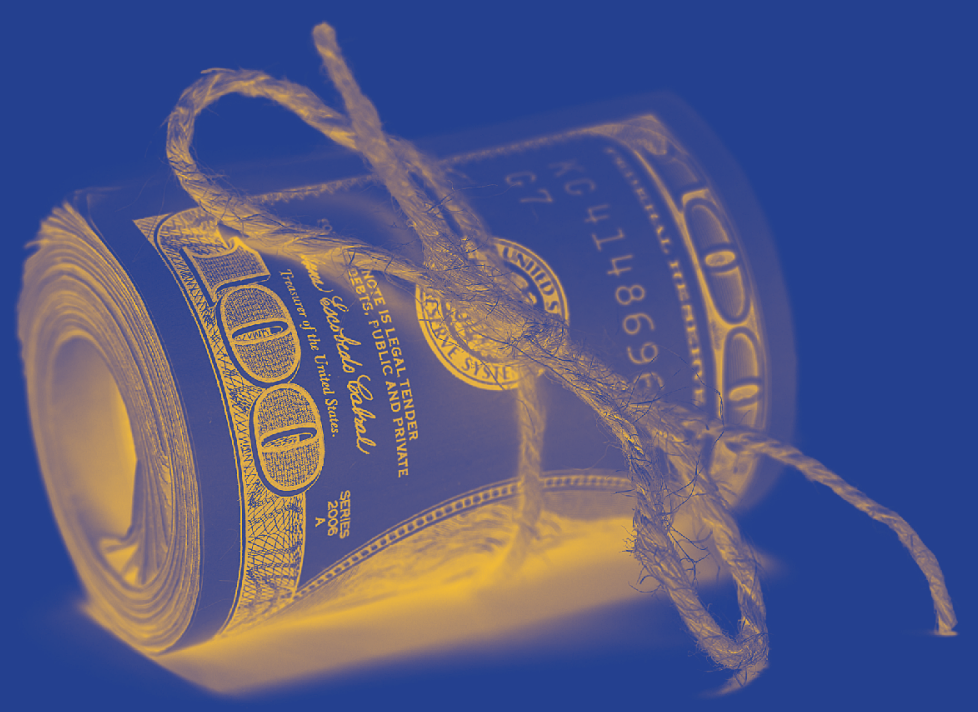



IZHODIŠČA MERJENJA — 


\section{口ob}


- KLAUDIJA ŠTERMAN IVANČIČ (UR.)

\section{IZHODIŠČA MERJENJA FINANČNE PISMENOSTI V RAZISKAVI PISA 2012 $S$ PRIMERI NALOG}


Klaudija Šterman Ivančič (ur.)

Izhodišča merjenja finančne pismenosti v raziskavi PISA 2012 s primeri nalog strokovna monografija

Digitalna knjižnica

Uredniški odbor: Igor Ž. Žagar (Educational Research Institute \& University of Primorska),

Jonatan Vinkler (University of Primorska), Janja Žmavc (Educational Research Institute),

Alenka Gril (Educational Research Institute)

Zbirka: Documenta, 8

Glavni in odgovorni urednik: Igor Ž. Žagar

Urednica zbirke: Alenka Gril

Recenzenta: Andreja Drobnič Vidic, Zlatan Magajna

Prevod izhodišč: Vesna Vrabič, Klaudija Šterman Ivančič

Prevod nalog iz finančne pismenosti: Ana Barič Moder, Barbara Müller, Majda Oblak

Tehnični urednik, oblikovanje, prelom in digitalizacija: Jonatan Vinkler

Lektor: Davorin Dukič

Založnik: Pedagoški inštitut

Gerbičeva 62, SI-1000 Ljubljana

Ljubljana 2013

Za založnika: Mojca Štraus

ISBN 978-961-270-196-3 (pdf)

http://www.pei.si/ISBN/978-961-270-196-3.pdf

ISBN 978-961-270-195-6 (html)

http://www.pei.si/ISBN/978-961-270-195-6/index.htm

DOI: https://www.doi.org/10.32320/978-961-270-196-3

(C) 2013 Pedagoški inštitut/Educational Research Institute

Publikacija je nastala v okviru projekta Ugotavljanje in zagotavljanje kakovosti v izobraževanju in usposabljanju - Evalvacija vzgoje in izobraževanja na podlagi mednarodno priznanih metodologij ki ga sofinancirata Evropski socialni sklad Evropske unije in Ministrstvo za izobraževanje, znanost in šport Republike Slovenije.

Zvirnik je vangleščcini objavil OECD pod naslovom: OECD (2013), PISA 2012 Assessment and Analytical Framework: Mathematics, Reading, Science, Problem Solving and Financial Literacy, PISA, OECD Publishing, http://dx.doi.org/10.1787/9789264190511-en @ 2013 OECD, vse pravice pridržane. @ 2013 Pedagoški inštitut, Slovenija, za slovensko izdajo. Za kakovost in usklajenost slovenskega prevoda zizvirnikom odgovarja Pedagoški inštitut V primeru kakršnega koli odstopanja prevoda od izvirnika se upošteva izvirnik.

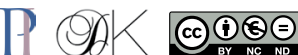

GIP - Kataložni zapis o publikaciii

a knižzica, Ljubliana

37.091.26:336(0.034.2)

IZHODIŠČA merienja finančne pismenosti v raziskavi PISA 2012 s primeri nalog [Elektronski vir] : strokovna monografija / Klaudija Šterman Ivančič (ur.); prevod Vesna Vrabič ... [et al.]. - El. knijiga. Ljubljana : Pedagoški inštitut, 2013. - (Digitalna knjižnica. Documenta ; 8 )

Način dostopa (URL): https://www.pei.si/ISBN/izhodisca-merjenja-financne-pismenosti-v-raziskavi-pisa-2012-s-primeri-nalog/

ISBN 978-961-270-195-6 (html)

1 Šterman lvančič Klaudija

270321920 


\section{Vsebina}

Kazalo tabel in slik 11

Predgovor 13

Predstavitev raziskave PISA $2012 \quad 15$

Organizacijske značilnosti raziskave PISA na mednarodni ravni 15

Raziskava PISA na nacionalni ravni 17

Vzroki za ugotavljanje finančne pismenosti 21

Povečana ponudba različnih vrst finančnih proizvodov in storitev 22

Dejavnosti OECD na področju finančnega izobraževanja 22

Finančno izobraževanje za mladostnike v šolah 23

Ugotavljanje finančne pismenosti v raziskavi PISA 2012

Zajem podatkov in poročanje o rezultatih v raziskavi PISA $2012 \quad 27$

Spremljajoča vprašanja za dijakinje in dijake $\quad 29$

Opredelitev finančne pismenosti

Finančna pismenost je poznavanje in razumevanje finančnih pojmov ... 32

... in veščin...

... motivacija in samozavest,... 32

... da posamezniki uporabijo to razumevanje in poznavanje pri sprejemanju učinkovitih odločitev ... 
... v različnih finančnih kontekstih ... 33

... da izboljšajo finančno blaginjo posameznikov in družbe ... 33

... in da lahko sodelujejo pri ekonomskih odločitvah. 33

Organizacija področja 33

Vsebina $\quad 34$

Denar in transakcije $\quad 35$

Načrtovanje in upravljanje financ 37

Tveganje in dobiček 39

Finančni zemljevid $\quad 41$

Proces $\quad 43$

Prepoznavanje finančnih podatkov 43

Razčlenjevanje podatkov znotraj finančnega konteksta $\quad 46$

Vrednotenje finančnih vprašanj $\quad 46$

Uporaba finančnega znanja in razumevanja $\quad 48$

Kontekst 49

Izobraževalni in delovni kontekst 50

Domači in družinski kontekst 50

Osebni kontekst 50

Družbeni kontekst 52

Drugi dejavniki finančne pismenosti 52

Dostop do informacij in finančnega izobraževanja 52

Dostop do denarja in finančnih proizvodov 53

Odnos do finančnih zadev in samozavest v omenjenih situacijah 53

Vedenjski vzorci trošenja in varčevanja 53

Finančna pismenost $v$ povezavi z matematično in bralno pismenostjo 55

Veščine računanja $\quad 55$

Branje in besedišče $\quad 57$ 


\begin{tabular}{lr} 
Naloge iz finančne pismenosti & $\mathbf{5 9}$ \\
\hline ODLOČITEV GLEDE IZDATKOV & 60 \\
DENAR ZA POTOVANJE & 62 \\
NOVA PONUDBA & 63 \\
NA TRŽNICI & 65 \\
PLAČILNA LISTA & 68 \\
NAPAKA BANKE & 70 \\
NOVA BANČNA KARTICA & 72 \\
DELNICE & 74 \\
ZAVAROVANJE MOTORNEGA KOLESA & 76 \\
\hline Povzetek & 79 \\
Summary & 81 \\
Literatura & 83 \\
Imensko in stvarno kazalo & 85
\end{tabular}





\section{Kazalo tabel in slik}

Tabela 1: Časovni potek raziskave PISA 2012 na šolah

Tabela 2: Opis ravni finančne pismenosti

Slika 1: Organizacijska struktura delovnih teles v raziskavi PISA 2012 16

Slika 2: Model organizacije področja za ugotavljanje finančne pismenosti 34

Slika 3: Odnos med vsebino finančne in matematične pismenosti v raziskavi PISA $2012 \quad 56$ 



\section{Predgovor}

Raziskava PISA je zasnovana kot dolgoročen mednarodni projekt, ki se pod okriljem organizacije OECD od leta 2000 izvaja na mednarodni ravni v triletnih ciklih. Slovenija se je v projekt vključila leta 2004, ko so se pričele priprave na glavni zajem podatkov v letu 2006. V raziskavi PISA 2012 je poleg Slovenije sodelovalo 66 držav, izmed tega 33 držav članic OECD in 33 držav partnerk. Glavni cilj raziskave je bilo tudi tokrat ugotavljanje kompetenc Is-letnikov s področij naravoslovne, matematične in bralne pismenosti, tokrat s poudarkom na matematični pismenosti. Slovenija pa je poleg ugotavljanja omenjenih kompetenc sodelovala tudi pri nekaterih dodatnih mednarodnih opcijah, ena izmed katerih je ugotavljanje finančne pismenosti - njena izhodišča v okviru raziskave PISA v slovenskem prostoru predstavljamo prvič.

Finančna pismenost je tako na mednarodni ravni kot v Sloveniji dokaj novo področje merjenja, pri ugotavljanju le-te pa je v ciklu raziskave PISA 2012 poleg Slovenije sodelovalo še 17 ostalih držav: Avstralija, Belgija, Šanghaj, Kolumbija, Hrvaška, Češka, Estonija, Francija, Izrael, Italija, Latvija, Nova Zelandija, Poljska, Rusija, Slovaška, Španija in ZDA.

Kompetence, ki jih mladi potrebujejo za učinkovito delovanje v današnji družbi, se hitro spreminjajo. Zaradi povečane razpoložljivosti mnogovrstnih produktov, hitro spreminjajočega se finančnega trga in tudi gospodarske krize ter posledično finančnih sprememb $\mathrm{v}$ družinah se je $\mathrm{v}$ zadnjem času zagotovo povečala potreba po spretnostih učinkovitega in varnega ravnanja s financami ter s tem povezanim tveganjem, ki vseskozi narašča. Finančna pismenost je po vsem svetu vedno bolj priznana tudi kot pomemben element gospodarske in finančne stabilnosti ter razvoja. Odgovornost za finančno preskrbljenost skozi vse življenje se od vlad in delodajalcev vedno bolj prenaša na posameznika in je učinkovito ravnanje ter vedenje na tem področju že v mladostniški dobi še kako pomembno. 
Publikacija, ki je pred vami, je namenjena vsem osnovnošolskim in srednješolskim učiteljem, učencem in dijakom ter vsem strokovnjakom, ki vas predstavljeno področje pri vašem raziskovalnem delu zanima. Predvsem pa upamo, da bodo objavljene naloge v učni praksi pogosto uporabljen vir pri razvijanju uporabe pri pouku usvojenega znanja v konkretnih, življenjskih situacijah.

Urednica 


\section{Predstavitev raziskave PISA 2012}

\section{Organizacijske značilnosti raziskave PISA na mednarodni ravni}

Sodelovanje velikega števila držav v mednarodni primerjalni raziskavi predstavlja zahtevno koordinacijo projekta in natančno določanje postopkov izvedbe, ki jim morajo slediti vse udeležene države. Tako deluje na mednarodni ravni več različnih delovnih teles, od katerih nekatera skrbijo za vsebinska vprašanja, druga pa so bolj osredotočena na samo izvedbo raziskave. Organizacijska struktura raziskave je nazorno prikazana na Sliki I (ur. Štraus, 2008), v nadaljevanju pa jo tudi na kratko opisujemo.

a) Sekretariat OECD

Sekretariat OECD s sedežem v Parizu je odgovoren za vodenje projekta PISA v celoti.

b) Mednarodni svet raziskave PISA - PGB

Mednarodni svet raziskave PISA - PISA Governing Board (PGB) nadzira in oblikuje izhodišča projekta in je sestavljen iz predstavnikov držav članic OECD in držav partnerk. PGB ima vodilno vlogo pri sprejemanju odločitev o konceptualni zasnovi raziskave PISA, določanju okvira zajemanja podatkov na področju merjenja znanja, smernicah nadaljnjega poteka raziskave, določanju glavnih korakov pri izvajanju raziskave, določanju in sprejemanju standardov izvedbe in načinov poročanja v raziskavi, odločanju o zasnovi mednarodnih poročil in interpretacij rezultatov raziskave, izvajanju razpisov za pripravo tematskih poročil o posebnih raziskovalnih področjih v raziskavi PISA ter odločanju o izboru prijaviteljev na razpise za sodelovanje v raziskavi. 


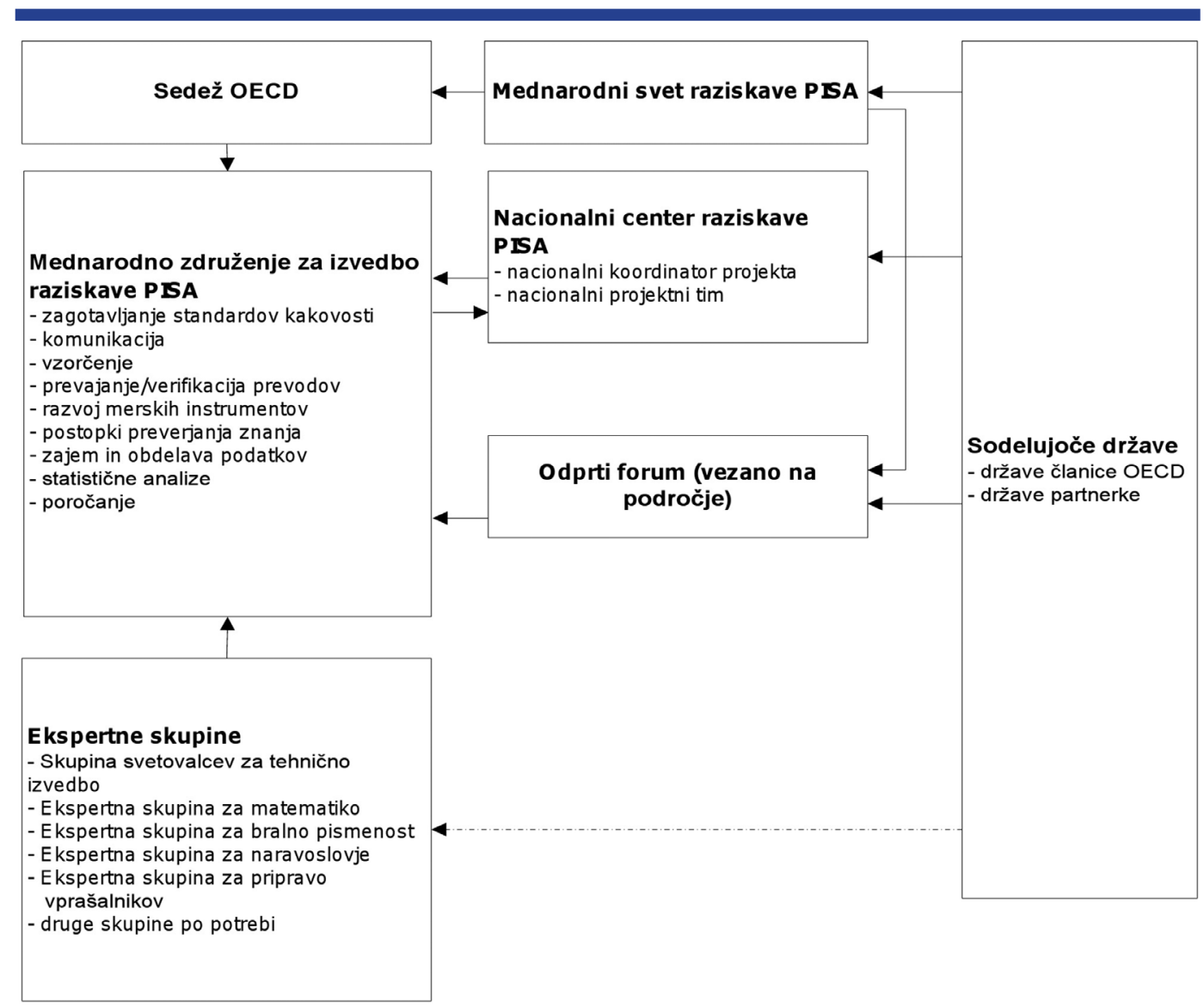

Slika ı: Organizacijska struktura delovnih teles v raziskavi PISA 2012

c) Mednarodno združenje organizacij

Mednarodno združenje organizacij je sestavljeno iz ıo organizacij, od katerih je imela v raziskavi PISA 2012 vodilno vlogo organizacija ACER (Australian Council for Educational Research). Ostale organizacije so naslednje: cApStAn Linguistic Quality Control, DIPF (Deutches Institut für Internationale Pädagogische Forschung), NIER Japan (National Institute for Educational Policy Research), aSPe (Unité d'analyse des systèmes et des pratique d'enseignement), Westat, ETS (Educational Testing Service), ILS (Institutt for Laererutdanning of Skoleforskning), IPN (Leibniz-Institute for Science and Mathemati- 
cs Education), NIER (National Institute for Educational Policy Research) in (CRP) Henri Tudor and Universite de Luxembourg (EMACS).

Naloga mednarodnega združenja organizacij je nadziranje razvoja in oblikovanje merskih inštrumentov (nalog in vprašalnikov) ter postopkov vzorčenja, prevajanje/verifikacija gradiv, oblikovanje postopkov preverjanja znanja na terenu, nadzor zajema in obdelave podatkov, statistične analize ter poročanje rezultatov. Veliko časa namenijo tudi spodbujanju odprte in učinkovite komunikacije med vsemi udeleženci v projektu ter tesnemu sodelovanju s predstavniki nacionalnih centrov. Skrbijo tudi za nenehno strokovno izobraževanje zaposlenih v nacionalnih centrih, zaradi lažjega uvajanja novosti, ki jih prinaša vsak posamezen cikel raziskave.

Posebno vlogo pa imajo v raziskavi PISA tudi različne ekspertne skupine, ki so ustanovljene z namenom neodvisnega svetovanja. Naj omenimo le nekatere:

d) Skupina svetovalcev za tehnično izvedbo raziskave - TAG (Technical Advisory Group)

Ta skupina svetuje pri tehničnih posebnostih, kot je na primer metodologija vzorčenja, poseben poudarek pa namenja zagotavljanju tehnično brezhibnih podatkov, zbranih $\mathrm{v}$ raziskavi.

e) Ekspertne skupine za posamezna področja merjenja

Za pripravo predlogov okvirov merjenja znanja posameznih področij pismenosti in zbiranje in pripravo predlogov nalog v mednarodnih preizkusih znanja delujejo Ekspertna skupina za bralno pismenost (Reading Expert Group, REG), Ekspertna skupina za matematiko (Mathematics Expert Group, MEG) in Ekspertna skupina za naravoslovje (Science Expert Group, $S E G$ ). Za pripravo predlogov vprašanj v mednarodnih vprašalnikih za zajemanje podatkov o spremljajočih dejavnikih, deluje Ekspertna skupina za pripravo vprašalnikov (Questionnaire Expert Group, QEG).

$\mathrm{V}$ posameznem ciklu raziskave PISA so ustanovljeni tudi različni forumi, kjer imajo strokovnjaki iz posameznih sodelujočih držav možnost zagovarjati interese in poglede svoje države pri nastajanju teoretičnih podlag (izhodišč) raziskave in razvoju inštrumentov merjenja.

\section{Raziskava PISA na nacionalni ravni}

Ministrstvo za šolstvo in šport je tudi v tem ciklu raziskave PISA naročnik in financer le-te (skrbnik pogodbe med OECD in Slovenijo), Slovenijo pa zastopa tudi v Mednarodnem svetu raziskave. Odgovornost za izvedbo raziskave v Sloveniji nosi Nacionalni cen- 
ter raziskave PISA iz Pedagoškega inštituta v Ljubljani. Za samo implementacijo raziskave je znotraj omenjenega centra odgovoren t. i. nacionalni koordinator raziskave - NPM (National Project Manager). Naloga nacionalnega centra je, da seznanja organizacije na mednarodni ravni s pogoji in ovirami pri izvedbi raziskave na nacionalni ravni, daje povratne informacije o razvojnih rešitvah in svetuje, na kakšen način bi raziskavo v določeni državi najbolje izvedli. Predvsem pa mora čim natančneje in skladno z mednarodno metodologijo, terminskim načrtom in standardi zagotoviti zanesljive podatke o dosežkih dijakov v posamezni državi.

Pri izvedbi raziskave PISA imajo pomembno vlogo tudi ravnatelji šol, ki samo izvedbo podpirajo in ustvarijo pogoje, da lahko le-ta steče, obenem pa aktivno sodelujejo pri izpolnjevanju »Vprašalnika za šolo «. Vsak izmed ravnateljev določi koordinatorja na šoli, ki z nacionalnim centrom ves čas priprav na izvedbo tesno sodeluje. Njegova vloga je ključna pri zagotavljanju kvalitetne izvedbe raziskave na šoli in predstavlja nekakšen vezni člen med dijaki, ki jih dobro pozna, ter izvajalcem, ki samo testiranje na šoli izvede.

Koordinator opravi vrsto nalog, ki jih moramo za uspešno izvedbo raziskave na šoli skupaj izvesti. Njegove najpomembnejše naloge so naslednje:

- na roditeljskih sestankih obvesti starše, da je šola udeležena v mednarodni raziskavi PISA,

- $\quad$ pripravi seznam dijakov, ki ustrezajo kriterijem ciljne populacije, in ga posreduje nacionalnemu centru,

- $\quad$ obvesti dijake, ki so izbrani za sodelovanje v raziskavi, o pomembnosti raziskave in njihovega sodelovanja ter jih motivira za sodelovanje,

- uskladi datume izvedbe raziskave na šoli z nacionalnim centrom,

- $\quad$ priskrbi ustrezen prostor za izvedbo raziskave na šoli in uskladi druge načrtovane dejavnosti za nemoteno šolsko delo,

- $\quad$ sodeluje z izvajalcem, sodelavcem PI, ki izvedbo na šoli izpelje, in mu pri sami izvedbi po potrebi pomaga,

- $\quad$ v primeru nadzora izvedbe na šoli sprejme nadzornika oz. sodelavca PI in mu posreduje potrebne informacije.

Poleg omenjenih sodelavcev v raziskavi, pa ne smemo pozabiti še pomembne vloge mnogih drugih, kot na primer izvajalcev na šolah, koderjev odgovorov odprtega tipa, koderjev poklicev, vnašalcev podatkov ter nadzornikov izvedb. Vsak izmed njih prispeva svoj delček v mozaiku del, ki jih je potrebno opraviti, da bi zagotovili kvalitetne nacionalne podatke. 
Osnovno in ključno vlogo pa imajo pri celotni izvedbi seveda dijaki ter njihovi starši, ki so v raziskavi pripravljeni sodelovati in brez katerih primerljivih rezultatov za Slovenijo ne bi bilo. 



\section{Vzroki za ugotavljanje finančne pismenosti}

Zadnjih nekaj let so razvite države in države v razvoju vedno bolj zaskrbljene zaradi stopnje finančne pismenosti svojih državljanov. Razlogi za to so krčenje javnih in zasebnih podpornih sistemov, spreminjanje demografskih profilov, kot je na primer staranje prebivalstva, in hiter razvoj finančnih trgov. Zaskrbljenost se je še povečala s finančno krizo in s spoznanjem, da je pomanjkanje finančne pismenosti eden izmed dejavnikov, ki prispevajo $\mathrm{k}$ slabim finančnim odločitvam posameznikov, in da imajo lahko te odločitve hude negativne posledice (INFE, 2009b; OECD, 2009a). Zato je zdaj finančna pismenost po vsem svetu priznana kot pomemben element gospodarske in finančne stabilnosti in razvoja (INFE, 2009b).

Zadnja leta se zelo širi prenos tveganja od vlad in delodajalcev na posameznike. Veliko vlad zmanjšuje ali pa je že zmanjšalo prispevke za pokojnine, nekatere pa zmanjšujejo tudi pravice zdravstvenega varstva. Večina raziskav kaže, da se večina zaposlenih ne zaveda tveganj, s katerimi se morajo zdaj soočiti, in da nimajo zadostnega znanja in veščin, da bi ustrezno upravljali tveganja, četudi se jih zavedajo (OECD, 2008). Poleg tega se polje tveganj, s katerimi se morajo ljudje spoprijeti, povečuje: posamezniki se na primer spopadajo $s$ tveganjem, povezanim z dolgo življenjsko dobo, zadolženostjo, finančnimi trgi in neposrednim plačilom storitev zdravstvenega varstva.

Število finančnih odločitev, ki jih mora sprejeti posameznik, se povečuje kot posledica sprememb na trgih in v gospodarstvu. Daljša pričakovana življenjska doba na primer pomeni, da morajo posamezniki zbrati več prihrankov, da pokrijejo veliko daljše obdobje upokojitve. Ljudje morajo tudi prevzeti več odgovornosti za financiranje osebnih ali družinskih zdravstvenih potreb. Poleg tega je zaradi naraščajočih stroškov izobraževanja pomembno, da starši primerno načrtujejo in vlagajo v izobraževanje svojih otrok. Medtem 
ko so te smeri razvoja najbolj očitne v razvitih državah, se podobne težave pojavljajo tudi v številnih gospodarstvih $\mathrm{v}$ razvoju.

\section{Povečana ponudba različnih vrst finančnih proizvodov in storitev}

Vedno več potrošnikov ima dostop do velikega števila različnih vrst finančnih proizvodov in storitev, in to od različnih ponudnikov in po različnih poteh. Posledica razvoja tehnologije in deregulacije je povečana dostopnost vseh vrst finančnih produktov, od tekočih računov do nakazil, kreditov in lastniških portfeljev. Proizvodi, ki so na voljo, postajajo vse bolj zapleteni, posamezniki pa morajo primerjati veliko dejavnikov, kot so stroški vodenja računa, prejete ali plačane obresti, trajanje pogodbe in izpostavljenost tveganju. Oceniti in izbrati morajo tudi ustrezne ponudnike in poti dostave iz široke množice možne izbire, med drugim tudi družbenih skupin, tradicionalnih finančnih ustanov, spletnih bank in ponudnikov storitev mobilne telefonije.

Potrošniki zlasti pogosto potrebujejo dostop do bank, da lahko pošljejo in sprejmejo elektronska plačila, kot so prihodki, nakazila in spletne transakcije, in tudi da opravijo neposredne transakcije v tistih družbah, ki ne poslujejo več z gotovino in čeki. Posamezniki, ki nimajo dostopa do bančnih storitev, pogosto plačajo več za gotovinske transakcije, tako da uporabijo neformalne finančne storitve, ki jih ponujajo npr. izposojevalnice denarja (glej npr. Kempson et al., 2005).

Posledica teh trendov je prenos odgovornosti za pomembne finančne odločitve na pleča posameznika, hkrati pa so povečali možnost izbire za večino ljudi in zapletenost finančnih odločitev. Pri vsem tem naj bi bil posameznik dovolj finančno pismen, da bi sebe in svoje sorodnike zaščitil ter sebi in njim zagotovil finančno varnost.

\section{Dejavnosti OECD na področju finančnega izobraževanja}

Leta 2003 je OECD začel daljnosežen finančnoizobraževalni projekt, da bi se odzval na vse večjo zaskrbljenost vlad glede možnih posledic slabe finančne pismenosti. S tem projektom se ukvarjata dva odbora OECD: Odbor za finančne trge (CMF) in Odbor za zavarovanja in zasebne pokojnine (IPPC). Leta 2008 je OECD oblikoval Mednarodno mrežo finančnega izobraževanja (INFE), ki naj bi uporabila in vključila izkušnje in znanje iz razvitih gospodarstev ter gospodarstev v razvoju. Trenutno je v mreži več kot I 38 javnih ustanov iz 68 držav. Člani se zberejo dvakrat na leto, da razpravljajo o najnovejših dogodkih v njihovih državah in da razvijejo analitične in primerjalne študije, metodologije, najboljšse prakse in smernice za glavna prednostna področja. V tem kontekstu je OECD in 
njegova mreža opredelila finančnoizobraževalne programe v šolah in mednarodno merjenje finančne pismenosti kot prednostne naloge ter ustanovila posebne podskupine strokovnjakov, da bi začeli poglobljeno zbirati podatke in razvijati programe.

\section{Finančno izobraževanje za mladostnike v šolah}

Finančno izobraževanje mladostnikov v šolah ali drugje ni nekaj novega. Kot smo že omenili, je finančna pismenost vedno bolj nujna življenjska veščina in že Priporočilo OECD iz leta 2005 priporoča, naj se »finančno izobraževanje začne v šoli. Ljudje bi se morali izobraziti o finančnih problemih tako zgodaj, kolikor je mogoče«(OECD, 2005b). Obstajata dva glavna razloga za to priporočilo: pomen osredotočanja na mladostnike in učinkovitost zagotavljanja finančne izobrazbe v šolah.

Mlajšim generacijam se ne bo treba spopasti le z vedno bolj kompleksnimi finančnimi proizvodi, storitvami in trgi, temveč bodo najverjetneje v odrasli dobi morale prevzemati več finančnih tveganj kot njihovi starši. Še posebno bodo morali odgovorneje načrtovati prihranke za upokojitev, investicije in pokritje stroškov za zdravstveno oskrbo; ubadati pa se bodo morali z bolj kompleksnimi in raznolikimi finančnimi proizvodi.

Zaradi sprememb na trgu delovne sile in sprememb pokojninskega sistema se današnje generacije verjetno ne bodo mogle učiti od preteklih. Morale se bodo zanašati na lastno znanje ali pa bodo zaradi zapletenosti novih sistemov morale uporabiti poklicne finančne svetovalce. Premalo finančnega izobraževanja v mladih letih in premalo zavedanja o koristih stalnega finančnega izobraževanja vodi $\mathrm{k}$ manjšemu finančnemu znanju na delovnem mestu in v drugih okoljih. Zato je pomembno, da zagotovimo zgodnje priložnosti za postavitev temeljev finančne pismenosti.

Poleg priprave mladih ljudi na odraslo življenje lahko finančno izobraževanje v šolah zajema tudi finančne teme, ki se neposredno tičejo mladih ljudi. Veliko otrok je od zgodnjega otroštva potrošnikov finančnih storitev. Ni neobičajno, da imajo spletne račune ali da uporabljajo mobilne telefone (z različnimi možnostmi plačevanja), še preden postanejo najstniki, in jasno je, da bi jim pri uporabi teh proizvodov koristile veščine finančne pismenosti. Preden zaključijo šolanje, se morajo že odločati o vprašanjih, kot so avtomobilsko zavarovanje, varčevalni proizvodi in bančni limiti.

V mnogih državah se med Is. in I 8. letom mladi ljudje (in njihovi starši) soočijo z eno najpomembnejših finančnih odločitev - ali naj investirajo v univerzitetno ali višjo izobrazbo. Razkorak med plačami univerzitetno izobraženih in neizobraženih delavcev se je v mnogih gospodarstvih povečal. Hkrati pa so se povečali stroški izobraževanja, ki jih nosijo študentje in njihovi starši. Podatki, objavljeni marca 2010 v Veliki Britaniji, kažejo, da 
polovica vseh britanskih študentov pričakuje, da bo študij zaključila s 15.000 britanskih funtov dolga.

Natančno merjenje finančne pismenosti pri mladih bo priskrbelo podatke na nacionalni ravni, ki bodo pokazali, ali je trenutni pristop $\mathrm{k}$ finančnemu izobraževanju učinkovit. Še posebno lahko pomaga ugotoviti probleme, ki se jim je treba posvetiti v šolah, ali pa potrebo po dodatnih aktivnostih ali programih, ki bodo omogočili mladim ljudem, da bodo primerno in enakovredno opremljeni za sprejemanje finančnih odločitev, ko odrastejo. Podatki bodo omogočili podlago, na kateri bomo lahko merili uspešnost programov in preučili šolske ter druge programe $\mathrm{v}$ prihodnosti.

Od mednarodne študije imajo koristi tudi oblikovalci politike in druge interesne skupine. Primerjava stopenj finančne pismenosti med državami omogoča vpogled v to, katere države imajo najvišje stopnje finančne pismenosti. Tako lahko identificiramo še posebno učinkovite nacionalne strategije in primere dobre prakse. Mogoče bo tudi prepoznati skupne izzive in raziskati možnosti rešitev problematičnih tem na mednarodni ravni.

Predvidevamo, da bo na tej podlagi zbiranje natančnih in mednarodno primerljivih podatkov o finančni pismenosti omogočilo izobraževalcem, načrtovalcem učnega načrta in gradiva, raziskovalcem, oblikovalcem politike in drugim, da bodo dobili:

- $\quad$ podatke o pomanjkljivostih $\mathrm{v}$ finančnem znanju med mladimi ljudmi, ki lahko pomagajo razviti bolje pripravljene programe in smernice;

- podatke o tem, ali trenutno finančno izobraževanje v šolah, kjer je izvajano, zvišuje stopnjo finančne pismenosti;

- $\quad$ sredstvo za primerjavo stopenj finančne pismenosti in s tem strategije mednarodnega finančnega izobraževanja;

- priložnost, da identificirajo primere dobre prakse na osnovi razvrstitev držav glede na stopnje finančne pismenosti; in na koncu

- primerljive podatke, ki jim bodo skozi daljše obdobje omogočili, da bodo ocenili vpliv pobud finančnega izobraževanja v šolah in ugotovili možnosti za nadaljnje izboljšave učinkovitosti.

\section{Ugotavljanje finančne pismenosti v raziskavi PISA 2012}

PISA 2012 je prva velika mednarodna raziskava, ki ocenjuje finančno pismenost mladostnikov. Pri merjenju znanja in veščin upošteva PISA finančno pismenost v vsej svoji širini. Ne meri le tega, kar se v šolah uči, temveč tudi pripravljenost mladih ljudi na življenje zunaj okvira obveznega šolanja in še posebno njihovo sposobnost, da uporabijo znanje 
in veščine. PISA zbira kognitivne in druge podatke o Is-letnikih v številnih državah in gospodarstvih. Tako lahko ponudi bogat nabor primerljivih podatkov, ki jih lahko uporabijo oblikovalci politike in druge interesne skupine, da se lahko odločijo na podlagi zanesljivih podatkov. Mednarodno primerljivi podatki o finančni pismenosti lahko odgovorijo na vprašanji, kot sta »Kako so mladostniki pripravljeni na nove finančne sisteme, ki postajajo globalni in vse bolj kompleksni? « in »Iz katere države prihajajo dijaki, ki so najboljši na področju finančne pismenosti?«

Tako kot pri glavnih področjih raziskave PISA (bralna, matematična in naravoslovna pismenost) je glavni poudarek ocenjevanja finančne pismenosti v raziskavi PISA na merjenju dosežkov I5-letnikov pri prikazu in uporabi znanja ter spretnosti. Finančno pismenost, kot tudi druge vrste pismenosti, ki jih preverja PISA, ocenjujemo z orodjem, ki omogoča podatke, ki so veljavni, zanesljivi in se jih da tolmačiti. 



\section{Zajem podatkov in poročanje o rezultatih $v$ raziskavi PISA 2012}

Finančno pismenost smo znotraj raziskave PISA 2012 preverjali s pomočjo delovnih zvezkov, ozadje dijakovih dosežkov pa s spremljajočimi vprašalniki.

Tabela ı: Časovni potek raziskave PISA 20 r2 na šolah

\begin{tabular}{|l|l|}
\hline Dejavnost & Čas \\
\hline Razdelitev gradiva in branje splošnih navodil & IO-I5 minut (približno) \\
\hline Reševanje delovnega zvezka & I ura (točno) \\
\hline Kratek odmor & 5 minut (največ) \\
\hline Reševanje delovnega zvezka & I ura (točno) \\
\hline Kratek vprašalnik na koncu delovnega zvezka & 5 minut (največ) \\
\hline Odmor & I5 minut \\
\hline Vprašalnik za dijakinje in dijake & 35 minut (približno) \\
\hline Zbiranje gradiva ob koncu izvedbe & $3-5$ minut (približno) \\
\hline Skupaj & 3 ure in 2o minut (približno) \\
\hline
\end{tabular}

V glavni zajem podatkov v raziskavi PISA 2012 je bilo vključenih 40 nalog iz finančne pismenosti, ki so bile razporejene v 2 skupka nalog, izmed katerih se za vsakega posebej predvideva 30 minut reševanja. Naloge iz omenjenih skupkov so bile razporejene na različna mesta $v 4$ različnih delovnih zvezkih. Ker se za reševanje celotnega testa v raziskavi PISA predvideva 120 minut (od tega 60 minut predstavljajo naloge iz finančne pismenosti), so preostali del testa sestavljale matematične ali bralne naloge (I sklop iz vsake dome- 
ne). Ker je ugotavljanje finančne pismenosti dodatna nacionalna opcija, je bil v vsakem srednješolskem programu za te potrebe izbran podvzorec 4-8 dijakov (od skupno 3 I ali 37), ki so izpolnjevali omenjene delovne zvezke. Torej, naloge iz finančne pismenosti niso bile vključene v vse delovne zvezke raziskave PISA, ampak le v nekatere, ki jih je izpolnjevalo le določeno število dijakov.

Reševanje nalog je na šolah potekalo 3 ure in 20 minut, in sicer po sledečem urniku:

Naloge finančne pismenosti so organizirane podobno kot pri ostalih glavnih področjih raziskave. Sestavlja jih uvodno besedilo, ki se osredotoča na finančne zadeve in je lahko v različnih oblikah, na primer v obliki besedila, diagramov, tabel, grafov in ilustracij, temu pa sledijo vprašanja zaprtega ali odprtega tipa. Torej, pri nekaterih vprašanjih morajo dijaki sami napisati odgovore, pri nekaterih pa izbirajo med danimi možnostmi. Naloge, pri katerih morajo dijaki sami napisati odgovor, imajo lahko odgovor v obliki ene same besede ali številke, lahko pa je tudi daljši - nekaj stavkov ali izračun. Tak tip nalog, ki zahteva daljši odgovor, je najprimernejši za zbiranje podatkov o sposobnosti dijakov, saj le-ti razložijo svoje odločitve ali prikažejo postopek analize. Pri nalogah, ki zahtevajo od dijakov, da izberejo en ali več mogočih odgovorov iz nabora možnosti, so najpogosteje na voljo štiri možnosti. Drug tip take naloge je naloga, pri kateri dijaki odgovarjajo na vrsto vprašanj tipa $\gg \mathrm{Da} / \mathrm{Ne} \ll$. Take naloge, pri katerih dijaki izbirajo odgovore, so navadno najbolj primerne za ocenjevanje nalog, ki so povezane $\mathrm{z}$ ugotavljanjem in prepoznavanjem podatkov, so pa tudi uporabne za merjenje učenčevega razumevanja kompleksnejših vsebin in pojmov, ki bi jih sami morda težko ubesedili.

Naloge pokrivajo velik razpon zahtevnosti. Na ta način je možno ugotoviti in opisati šibke in močne točke populacije.

Tudi pri finančni pismenosti uvrščamo dosežke dijakov na posameznih nalogah na t. i. lestvico finančne pismenosti (OECD, 2013), in sicer na 4 ravni (glej tabelo 2 spodaj). Zasnova testa PISA omogoča konstrukcijo enotne lestvice dosežkov, kjer so upoštevani tako zahtevnost naloge kot dijakove spretnosti in znanje. Vsako vprašanje testa se uvršča na točno določeno točko na lestvici, ki označuje njegovo zahtevnost, obenem pa je s točno določenim mestom na lestvici povezan tudi uspeh dijaka, ki ga pri tem vprašanju glede na njegovo uspešnost pri ostalih vprašanjih predvidevamo.

Zahtevnost naloge se tako določa na podlagi deleža dijakov, ki so nalogo pravilno rešili, dijakova uspešnost pri določenem vprašanju pa se določi na podlagi deleža vprašanj, ki jih je dijak pravilno odgovoril. Enotna lestvica tako prikazuje odnos med zahtevnostjo vprašanj in uspešnostjo reševalca le-teh. Ker lestvica zajema zahtevnost vsakega vprašanja, 
je na podlagi tega možno določiti tudi nivo finančnega znanja, ki ga vprašanje zahteva, in (finančno) znanje, ki ga ima dijak.

Na podlagi uspešnosti dijaka na testu lahko tako predvidevamo, katera vprašanja bo rešil uspešno. Dijak bi najverjetneje pravilno odgovoril na vprašanja, ki se nahajajo na ali pod ravnjo pismenosti, na katero se uvršča na lestvici. Nasprotno pa je manjša verjetnost da bi pravilno odgovoril na vprašanja, ki se nahajajo nad to ravnjo. Višja kot je raven finančne pismenosti dijaka na lestvici v primerjavi s točko, na kateri se nahaja vprašanje, bolj je verjetno, da bo nanj pravilno odgovoril in obratno.

Tabela 2: Opis ravni finančne pismenosti

\begin{tabular}{|c|c|}
\hline Raven & Kompetence, ki jih izkazuje dijak na tej ravni finančne pismenosti \\
\hline 4 & $\begin{array}{l}\text { Dijak, ki izkazuje znanje in spretnosti na četrti ravni finančne pismenosti, učinkovito prepoznava in uporablja } \\
\text { razumevanje manj poznanih finančnih konceptov ter produktov, ki bodo zanj pomembni šele v prihodnosti. } \\
\text { Zna interpretirati in vrednotiti zelo specifične finančne podatke, kot je na primer bančni izpisek. Oblikuje pojasnila, ki se } \\
\text { nanašajo na funkcijo dokaj nepoznanih finančnih produktov in poda utemeljitev za svoje relativno kompleksne } \\
\text { finančne odločitve. Pri reševanju finančnih problemov tudi učinkovito uporablja spretnosti računanja. }\end{array}$ \\
\hline 3 & $\begin{array}{l}\text { Dijak, ki izkazuje znanje in spretnosti na tretji ravni finančne pismenosti, prepoznava in uporablja svoje razume- } \\
\text { vanje različnih finančnih terminov in konceptov. Ućmkovito interpretira in ovrednoti finanćne dokumente, pri čemer } \\
\text { uspešno uporabi spretnosti računanja. Izkazuje razumevanje finančnih produktov v danem kontekstu, kot je npr. de- } \\
\text { pozit, in poda pojasnilo za svojo finančno odločitev, ki bo zanj pomembna na prehodu v odraslost. }\end{array}$ \\
\hline 2 & $\begin{array}{l}\text { Dijak, ki izkazuje znanje in spretnosti na drugi ravni finančne pismenosti, prepoznava poznane finančne kon- } \\
\text { cepte in termine v določenem kontekstu ter to razumevanje uporabi pri dokaj jasnih finančnih odločitvah, ki } \\
\text { zahtevajo enostavne izračune. Ućinkovito interpretira enostavne finanćne dokumente in izkazuje sirš́e razumevanjef- } \\
\text { nančnih produktov, skaterimi se bo podrobneje srećal po zakljucenem solanju, kot so bančni račun in zavarovanje. Izkazuje } \\
\text { razumevanje razlike med željami in dejanskimi potrebami v vakdanjem kontekstu. }\end{array}$ \\
\hline I & $\begin{array}{l}\text { Dijak, ki izkazuje znanje in spretnosti na najnižji ravni finančne pismenosti, prepoznava poznane finančne ter- } \\
\text { mine. Informacije interpretira na podlagi osnovnih finančnih konceptov. Identificira in pojasni uporabo vsakdanjih finančnih } \\
\text { produktov. Izkazuje osnovne veščine računanja v finančnem kontekstu. V sklopu finančnega načrtovanja prepo- } \\
\text { znava razliko med željami in dejanskimi potrebami v vsakdanjih kontekstih. }\end{array}$ \\
\hline
\end{tabular}

\section{Spremljajoča vprašanja za dijakinje in dijake}

$\mathrm{V}$ okviru ugotavljanja finančne pismenosti v raziskavi PISA 2012 so se strokovnjaki s pomočjo dodatnih vprašanj ob koncu delovnih zvezkov odločili ugotavljati tudi štiri nekognitivne dejavnike, ki so pomembni pri razumevanju stopnje finančne pismenosti, ki jo dijak dosega. Le-ti se navezujejo na odnos do finančnih zadev ter vedenje v omenjenih situacijah in so naslednji: dostop do informacij in finančnega izobraževanja, dostop do denarja in finančnih proizvodov, odnos do finančnih zadev in samozavest v omenjenih situacijah ter vedenjski vzorci trošenja in varčevanja. Podrobneje jih opisujemo na strani XX. 
Dijaki, ki so izpolnjevali delovne zvezke z nalogami finančne pismenosti, pa so, kot vsi ostali, ob koncu reševali še enake Vprašalnike za dijakinje in dijake, v katerih smo spraševali po:

- družinskem ozadju dijakov, vključno z gospodarskim, socialnim in kulturnim kapitalom;

- učenju matematike in dijakovih matematičnih izkušnjah;

- dijakovih izkušnjah z reševanjem problemov;

- kakovosti človeških virov na šoli in po materialnih virih, načinu organiziranja in financiranja šole (javna ali zasebna šola), procesih sprejemanja odločitev in praksah zaposlovanja;

- vsebini učnih praks, vključno s tipi in strukturami izobraževalnih sistemov, velikostjo razreda in oblikami sodelovanja staršev;

- strategijah samostojnega učenja, motivaciji in postavljenih ciljih, kognitivnih mehanizmih, kontrolni strategiji, naklonjenosti različnim tipom učnih situacij, slogih učenja in socialni spretnosti, potrebni za sodelovanje ter učenje;

- oblikah učenja in poučevanja pri matematiki;

- splošni uporabi in razpoložljivosti informacijsko komunikacijske tehnologije;

- odnosu dijaka do računalnikov;

- izobraževanju v prihodnosti ter morebitni pomoči pri jezikovnem izobraževanju. 


\section{Opredelitev finančne pismenosti}

Pri razvijanju definicije finančne pismenosti je skupina strokovnjakov upoštevala tako splošno opredelitev pismenosti znotraj raziskave PISA kot tudi znanje o naravi finančnega izobraževanja.

PISA pismenost v splošnem opredeljuje kot sposobnost dijakov, da uporabijo znanje in veščine na ključnih področjih šolskih predmetov in da razčlenijo, utemeljijo in učinkovito komunicirajo, ko postavljajo, rešujejo in interpretirajo naloge v različnih situacijah. PISA se osredotoča na prihodnost, na sposobnost mladih ljudi, da uporabijo znanje in veščine, da se spopadejo z dejanskimi izzivi in ne le, da pokažejo, v kolikšni meri so usvojili vsebino specifičnega učnega načrta (OECD, 2010).

OECD je opredelil finančno izobraževanje kot »proces, pri katerem posamezniki izboljšujejo svoje razumevanje finančnih proizvodov in konceptov ter s pomočjo podatkov, poučevanja in/ali objektivnih nasvetov razvijajo veščine in samozaupanje, da se začnejo bolje zavedati finančnih tveganj in priložnosti, da se lahko odločajo na podlagi podatkov, da vedo, na koga naj se obrnejo po pomoč, in da znajo pravilno ukrepati, da izboljšajo svoje finančno stanje ter zaščito.« (OECD, 2005b)

Definicija finančne pismenosti v raziskavi PISA 2012 je naslednja:

Finančna pismenost je posameznikovo poznavanje in razumevanje finančnih pojmov in vešcin, zajema pa tudi motivacijo in samozavest, da uporabi to poznavanje in razumevanje pri sprejemanju ućinkovitih odlocitev v razlicnih finanćnih kontekstih, da izboljš finančno stanje posameznikov in družbe in da labko sodeluje v ekonomskih odlocitvah.

V naslednjih odstavkih obravnavamo vse dele opredelitve finančne pismenosti v raziskavi PISA 2012 podrobneje. 
Finančna pismenost je poznavanje in razumevanje finančnih pojmov ...

Seveda ne moremo pričakovati, da bodo is-letniki imeli poglobljeno finančno znanje ali da bodo razumeli kompleksnost osebnih financ. Lahko pa predvidevamo, da se vsaj malo zavedajo finančnega okolja, v katerem živijo oni in njihove družine. Vsi so najbrž že kupovali predmete za gospodinjstvo ali osebno rabo; nekateri so sodelovali v družinskih pogovorih o denarju in o tem, ali res potrebujejo, kar hočejo; in precejšen odstotek je že začel služiti denar in varčevati. Nekateri dijaki že imajo izkušnje s finančnimi proizvodi, kot sta bančni račun ali pogodba za mobilni telefon. Razumevanje konceptov, kot so obrestna mera, inflacija in ugoden nakup, bo kmalu, če že ni, pomembno za njihov finančni blagor. Čeprav preprosta reprodukcija znanja ni najpomembnejši del ocenjevanja raziskave PISA, je finančna pismenost odvisna od poznavanja temeljnih elementov finančnega sveta, tudi finančnih proizvodov, kot so zavarovalne police in pokojnine.

... in veścin...

Te veščine vključujejo splošne kognitivne procese, kot so dostopanje do podatkov ter primerjanje in ocenjevanje - v finančnem kontekstu. Vključujejo osnovne veščine matematične pismenosti, kot so sposobnost izračunavanja odstotkov ali pretvorbe zneska iz ene valute v drugo, ter jezikovne spretnosti, kot sta bralna sposobnost in sposobnost tolmačenja oglaševalnih ter pogodbenih besedil. Poleg tega finančna pismenost vključuje tudi veščino obvladovanja čustvenih in psiholoških dejavnikov, ki vplivajo na finančne odločitve.

... motivacija in samozavest,...

Finančna pismenost ne vključuje le znanja, razumevanja in sposobnosti, da se ukvarjamo s finančnimi temami, temveč tudi motivacijo za iskanje podatkov, nasvetov in spopadanjem s finančnimi aktivnostmi, ter samozaupanje. Te lastnosti naj bi bile cilj finančnega izobraževanja, so pa tudi ključnega pomena pri pridobivanju finančnega znanja in spretnosti.

... da posamezniki uporabijo to razumevanje in poznavanje pri sprejemanju ucinkovitih odlocitev ...

PISA se osredotoča na sposobnost aktiviranja znanja in razumevanja v vsakdanjih situacijah. Ko ocenjujemo finančno pismenost, se ta kaže v stopnji mladostnikove sposobnosti, da to, kar se je naučil o osebnih financah, uporabi pri učinkovitem odločanju. 
... v različnih finančnih kontekstih ...

Učinkovite finančne odločitve se nanašajo na različne finančne kontekste, ki jih mladostniki danes srečujejo v vsakdanjem življenju in izkušnjah, a tudi na korake, ki jih bodo naredili v bližnji prihodnosti kot odrasli ljudje. Mladi na primer mogoče trenutno sprejemajo razmeroma preproste odločitve, kot na primer, kako bodo porabili žepnino, ali pa celo (že), kakšno pogodbo z mobilnim operaterjem bodo sklenili, toda kmalu bodo morali sprejemati pomembne odločitve o izobraževanju in delu z dolgotrajnimi finančnimi posledicami.

\section{... da izboljšajo finančno blaginjo posameznikov in družbe ...}

Finančna pismenost je $v$ študiji PISA zamišljena najprej kot osebna finančna pismenost, ki se razlikuje od ekonomske pismenosti, ki vključuje širše koncepte, kot so teorije o ponudbi in povpraševanju, tržnih strukturah in tako naprej. Finančna pismenost se ukvarja s tem, kako posamezniki razumejo, upravljajo in načrtujejo osebne finančne zadeve in finančne zadeve svojega gospodinjstva oziroma družine. Razume se, da imajo posameznikovo dobro razumevanje, upravljanje in načrtovanje tudi določen kolektivni vpliv na širšo družbo - tako, da prispevajo $\mathrm{k}$ nacionalni ali celo $\mathrm{h}$ globalni stabilnosti, produktivnosti in razvoju.

\section{... in da labko sodelujejo pri ekonomskih odlocitvah.}

Tako kot opredelitve drugih pismenosti v raziskavi PISA opredelitev finančne pismenosti kaže na pomen vloge posameznika kot premišljenega in polno sodelujočega člana družbe. Posamezniki z visoko stopnjo finančne pismenosti so bolje opremljeni za sprejemanje odločitev, ki imajo neposredno korist zanje, in tudi za konstruktivno podpiranje ter vrednotenje ekonomskega sveta, v katerem živijo.

\section{Organizacija področja}

Organizacija področja določa načrt ugotavljanja finančne pismenosti kot tudi sestavljanje nalog ter še posebej zbiranje ter poročanje o doseganju stopnje finančne pismenosti dijakov. Kot je razvidno iz slike spodaj, finančno pismenost v raziskavi PISA 2012 opredeljujejo tri temeljne dimenzije, in sicer vsebina, kontekst in proces. Vsebina pokriva področja znanja in razumevanja, ki so nujna za področje pismenosti, procesi opisujejo umske strategije ali pristope, ki jih uporabimo, da se spopademo z danim gradivom, kontekst pa se navezuje na situacije, $\mathrm{v}$ katerih se znanje, veščine in razumevanje nekega področja uporabljajo. Situacije so lahko tako osebne kot tudi globalne. 
Vsaka posamezna naloga iz finančne pismenosti tako zajema vse tri omenjene dimenzije, ki jih podrobneje predstavljamo v nadaljevanju.

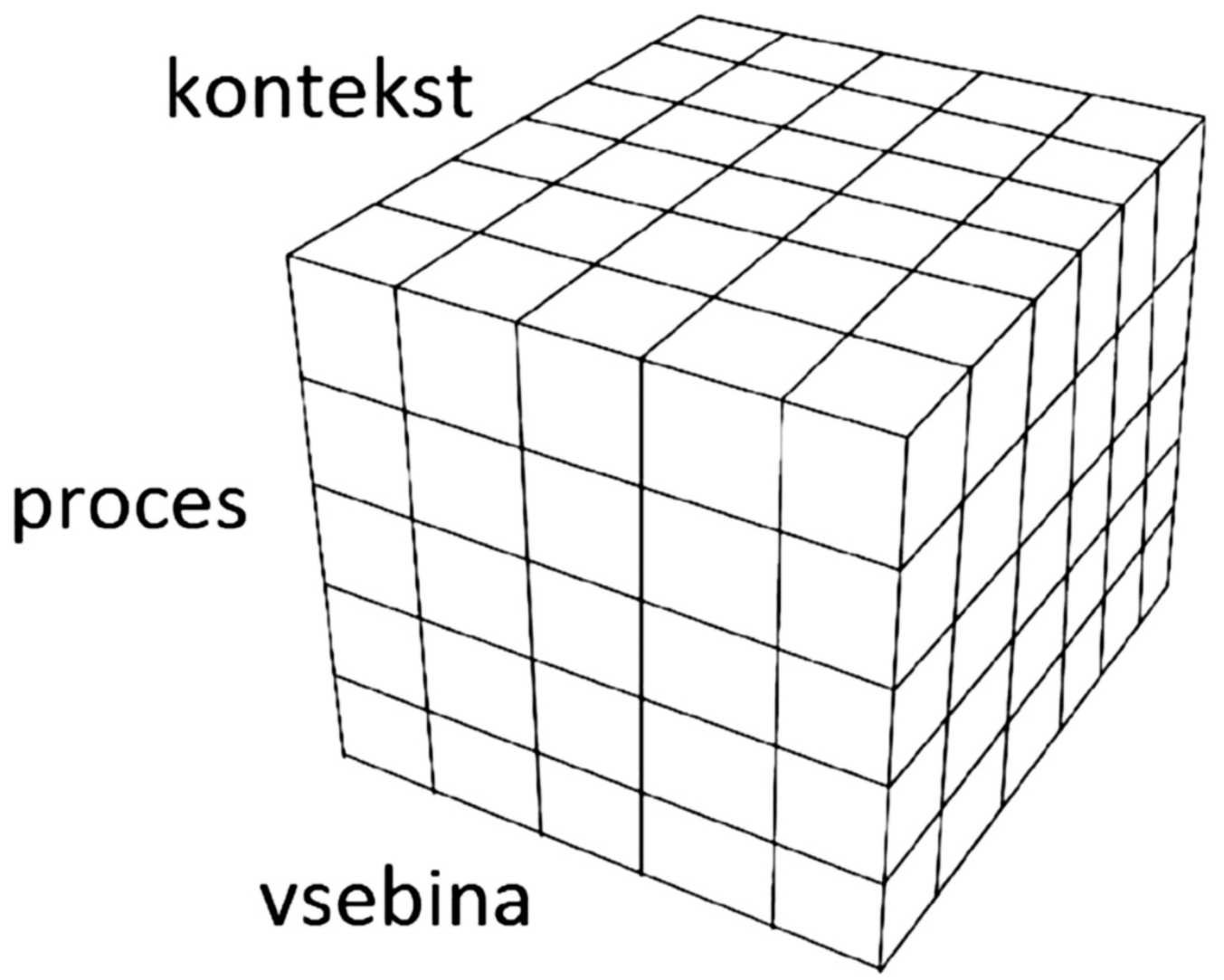

Slika 2: Model organizacije področja za ugotavljanje finančne pismenosti

\section{Vsebina}

Vsebina finančne pismenosti so področja znanja in razumevanja, ki ga moramo uporabiti, da izvedemo določeno nalogo. Pregled vsebine okvirov finančnega izobraževanja iz velikega števila držav (Avstralija, Brazilija, Anglija, Japonska, Malezija, Nizozemska, Nova Zelandija, Severna Irska, Škotska, Južna Afrika in ZDA) kaže, da obstaja določeno soglasje o tem, katera so vsebinska področja finančne pismenosti (INFE, 2009a; Watson, 
2009). Analiza podatkov je pokazala, da je bila vsebina finančnega izobraževanja v šolah kljub kulturnim razlikam razmeroma podobna in da je mogoče identificirati vrsto tem, ki so vključene v te izobraževalne okvire. Te tvorijo štiri vsebinska področja za finančno pismenost, ki jo raziskuje PISA: denar in transakcije, načrtovanje in upravljanje financ, tveganje in dobiček ter finanćni zemljevid.

\section{Denar in transakcije}

To vsebinsko področje se osredotoča na širok spekter osebnih finančnih tem, kot so vsakodnevna plačila, poraba, ugodni nakupi, bančne kartice, čeki, bančni računi in valute. To vsebinsko področje vsebuje naloge, ki preverjajo, ali dijaki:

- razumejo, da denar menjamo za dobrine in storitve;

- prepoznajo bankovce in kovance;

- poznajo različne načine plačevanja za predmete, osebno ali prek spleta;

- znajo izračunati, koliko drobiža ostane po plačilu;

- znajo izračunati, kateri izmed dveh različno velikih potrošniških predmetov omogoča ugodnejši nakup, če upoštevajo posebne potrebe in okoliščine posameznika;

- razumejo, da ljudje prejemajo denar na različne načine in da obstajajo različni načini izmenjave denarja med ljudmi in organizacijami;

- znajo uporabljati bančne avtomate, da dvignejo gotovino ali preverijo stanje na računu;

- znajo preveriti transakcije na bančnem izpisku in opazijo nepravilnosti;

- razumejo, da denar lahko posojamo ali si ga izposodimo, in poznajo razloge za plačevanje ali prejemanje obresti; in

- znajo uporabiti kreditno ali debetno kartico.

Naslednja naloga ponazarja primer vprašanja, pri katerem mora dijak upoštevati koncept ugodnega nakupa. Valuta Zed, ki je v njej uporabljena, je izmišljena, o čemer so dijaki predhodno obveščeni. Uporaba tovrstne valute omogoča primerljivost med državami, kar bi bilo z uporabo dejanske valute določene države oteženo. 
Primer šl. 1: NA TRŽNICI

Paradižnike lahko kupiš na kilogram ali na zaboj.

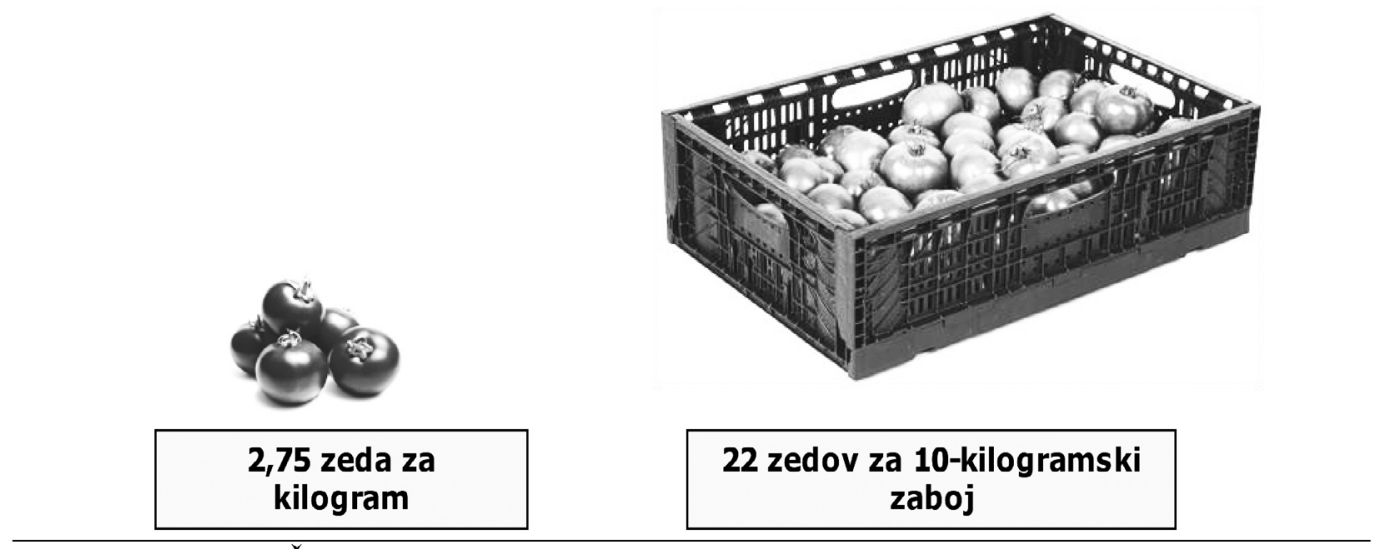

Vprašanje: NA TRŽNICI

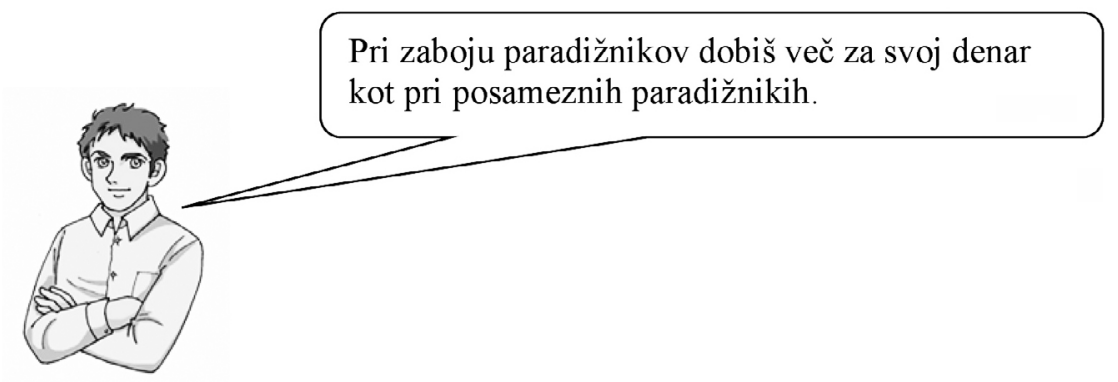

Navedi razlog, ki podpira to trditev.

Z uporabo vsakodnevnega konteksta, kot je nakupovanje živil, se naloga nanaša na osnovni koncept ugodnega nakupa. Vprašanja, ki se nanašajo na nakupovanje potrebščin, so po večini uvrščena v vsebinski sklop denar in transakcije. Da je dijak dobil točko za pravilen odgovor pri tem vprašanju, je moral, glede na določen kriterij, primerjati dva načina nakupa paradižnika. Sledijo primeri pravilnih odgovorov:

- Kgposameznih paradižnikov stane 2,75 zeda, kgparadižnikov v zaboju pa samo 2,2 zeda.

- Ker bi io kg posameznih paradižnikov stalo 27,50 zeda. 
- Dobišveč kgza vsakzed, ki ga plačaš.

V predraziskavi PISA 2012 je približno 75 \% vseh sodelujočih dijakov uspešno analiziralo informacijo in pojasnilo, zakaj je cena kilograma paradižnikov v zaboju nižja od kilograma posameznih paradižnikov.

\section{Načrtovanje in upravljanje financ}

Denar in premoženje zahtevata kratkoročno in dolgoročno načrtovanje in upravljanje. To vsebinsko področje vsebuje naloge, ki preverjajo, ali dijaki:

- prepoznajo različne oblike in stopnje dohodkov (na primer žepnina, plača, provizija, ugodnosti, urna postavka ter bruto in neto dohodek);

- azumejo, kaj so davki in olajšave ter kako vplivajo na načrtovanje in upravljanje denarja;

- znajo načrtovati proračun za redno potrošnjo in varčevanje;

- razumejo, kako upravljati različne elemente proračuna, kot je ugotavljanje prednostnih nakupov, če se dohodek ne ujema z načrtovanimi stroški, ali znajo poiskati možnosti za zmanjševanje stroškov, da povečajo količino privarčevanega denarja;

- znajo vnaprej načrtovati stroške $\mathrm{v}$ prihodnosti (na primer, koliko morajo prihraniti vsak mesec za neki nakup);

- znajo oceniti vpliv različnih načrtov nakupovanja, da se odločijo na podlagi informacij;

- razumejo idejo o plemenitenju premoženja, idejo o vplivu obrestnih obresti na varčevanje ter prednosti in pomanjkljivosti investicijskih proizvodov;

- prepoznajo prednosti načrtovanja $\mathrm{v}$ zgodnjih letih za upokojitev in pomen finančnih rezerv v primeru stiske;

- razumejo prednosti varčevanja za druge dolgoročne cilje ali pričakovane spremembe okoliščin (kot je na primer rojstvo otroka);

- znajo oceniti prednosti in pomanjkljivosti investiranja v človeški kapital skozi različne oblike izobraževanja in usposabljanja; in

- razumejo smisel izposojanja denarja in dejstvo, da lahko izdatke uravnavamo s pomočjo izposojanja ali varčevanja.

Vsebinski sklop načrtovanje in upravljanje financ je torej pomemben pri načrtovanju življenja Is-letnika v njegovi bližnji prihodnosti. Spodaj navajamo primer naloge, ki jo uvrščamo v ta sklop. 
Primer št. 2: ODLOČITEV GLEDE IZDATKOV

Cvetka in njene prijateljice najamejo hišo.

Vse so zaposlene že dva meseca.

Nimajo nobenih prihrankov.

Plačane so enkrat mesečno in pravkar so prejele plačo.

Naredile so seznam stvari, ki jih je treba narediti.

\section{Kaj je treba narediti}

- Naročitukabelsko TV

- Plačati najemnino

- Kupituvrtnopohistvo

Vprašanje: ODLOČITEV GLEDE IZDATKOV

Katerim od nalog na seznamu se bodo morale Cvetka in njene prijateljice verjetno kmalu posvetiti?

Pri vsaki nalogi obkroži "Da" ali "Ne".

\begin{tabular}{|l|c|}
\hline \multicolumn{1}{|c|}{ Naloga } & $\begin{array}{c}\text { Ali je verjetno, da se bo treba tej nalogi kmalu } \\
\text { posvetiti? }\end{array}$ \\
\hline Naročiti kabelsko TV & $\mathrm{Da} / \mathrm{Ne}$ \\
\hline Plačati najemnino & $\mathrm{Da} / \mathrm{Ne}$ \\
\hline Kupiti vrtno pohištvo & $\mathrm{Da} / \mathrm{Ne}$ \\
\hline
\end{tabular}

Navedeno vprašanje od dijaka zahteva oceno prioritet pri razporejanju družinskega proračuna ter razločevanje med željami in dejanskimi potrebami. Približno 75 \% vseh sodelujočih dijakov je na vprašanje odgovorilo pravilno tako, da so obkrožili $N e, D a, N e, v$ 
tem vrstnem redu. Na ta način so razumeli, da je za Cvetko in sostanovalke najprej pomembno to, da plačajo najemnino.

Naslednja naloga, ki jo prav tako uvrščamo v vsebinski sklop načrtovanje in upravljanje financ, je naloga DENAR ZA POTOVANJE, navedena pod primerom št. 9 na strani 49.

\section{Tveganje in dobiček}

Tveganje in dobiček je ključno področje osebne finančne pismenosti in vključuje razumevanje možnosti finančnega dobička ali izgube $\mathrm{v}$ različnih finančnih kontekstih in sposobnost, da prepoznamo načine za upravljanje, uravnovešanje in pokrivanje tveganj. Na tem področju obstajata dve pomembni tveganji. Prvo se nanaša na finančne izgube, ki jih posameznik ne more prenesti, kot so na primer tiste, ki jih prinesejo katastrofalni stroški ali stroški, ki se ponavljajo. Drugo je tveganje, ki je prisotno v finančnih proizvodih, kot so kreditne pogodbe s fleksibilnimi obrestnimi merami.

To vsebinsko področje vključuje razumevanje, zakaj so nekatere metode varčevanja ali investiranja bolj tvegane kot druge. Vključuje tudi razumevanje, kako omejiti tveganje osebnega kapitala. Dijaki morajo vedeti, da obstajajo raznoliki zavarovalniški produkti, ki so primerni za različne potrebe in okoliščine. Naloge na tem vsebinskem področju raziskujejo morebitna tveganja ali koristi, ki so povezane z:

- različnimi tipi investicij in oblikami varčevanja, tudi formalnimi finančnimi proizvodi in alternativnimi načini varčevanja (kot na primer nakup živine ali zlata), in zavarovalniškimi proizvodi;

- različnimi oblikami posojil, tudi neformalnimi in formalnimi posojili, zavarovanimi in nezavarovanimi posojili, vrtljivim kreditom (ko skupina ljudi vsak mesec vloži denar v skupno blagajno, nato pa iz nje vsak mesec črpa drug posameznik) in namenskim kreditom ter posojili s fiksno in fleksibilno obrestno mero;

- neizpolnitvijo obveznosti pri plačilu računov in posojilnih obveznosti; in

- nihanjem obrestnih mer in menjalnih tečajev ter nestanovitnostjo trga.

Naslednjo nalogo uvrščamo v vsebinski sklop tveganje in dobiček. 
Primer št. 3: ZAVAROVANJE MOTORNEGA KOLESA

Lani je bilo Simonovo motorno kolo zavarovano pri zavarovalnici PRAVA ZAVAROVALNICA.

Zavarovalna polica je krila škodo na motornem kolesu v primeru nesreče in kraje motornega kolesa.

Vprašanje: ZAVAROVANJE MOTORNEGA KOLESA

Simon namerava letos podaljšati zavarovanje pri PRAVI ZAVAROVALNICI, vendar se je od lani v Simonovem življenju spremenilo več dejavnikov.

Kako utegne vsak od dejavnikov v tabeli vplivati na strošek Simonovega letošnjega zavarovanja za motorno kolo?

Pri vsakem dejavniku obkroži "Poveča strošek", "Zmanjša strošek" ali "Ne vpliva na strošek".

\begin{tabular}{|l|c|}
\hline \multicolumn{1}{|c|}{ Dejavnik } & $\begin{array}{c}\text { Kako utegne ta dejavnik vplivati na } \\
\text { strošek Simonovega zavarovanja? }\end{array}$ \\
\hline $\begin{array}{l}\text { Simon je svoje staro motorno kolo zamenjal za } \\
\text { veliko močnejše motorno kolo. }\end{array}$ & $\begin{array}{c}\text { Poveča strošek / Zmanjša strošek/ } \\
\text { Ne vpliva na strošek }\end{array}$ \\
\hline Simon je motor prebarval z drugačno bravo. & $\begin{array}{c}\text { Poveča strošek / Zmanjša strošek / } \\
\text { Ne vpliva na strošek }\end{array}$ \\
\hline Simon je lani povzročil dve prometni nesreči. & $\begin{array}{c}\text { Poveča strošek / Zmanjša strošek / } \\
\text { Ne vpliva na strošek }\end{array}$ \\
\hline
\end{tabular}

Zavarovanje je produkt, ki je namenjen zaščiti posameznika pred tveganjem in finančno izgubo. Navedeno vprašanje od dijaka zahteva razumevanje, da večja kot je, glede na določene kriterije, izpostavljenost tveganju, več bo stalo ustrezno zavarovanje. Približno $50 \%$ sodelujočih dijakov v predraziskavi je pravilno prepoznalo, da prvi in tretji dejavnik povečujeta stroške zavarovanja, medtem ko drugi dejavnik na to nima nobenega vpliva.

Naslednja naloga, navedena pod primerom št. 6, na strani 45, ki jo prav tako uvrščamo $\mathrm{v}$ vsebinski sklop tveganje in dobiček, se imenuje DELNICE. 


\section{Finančni zemljevid}

To vsebinsko področje se nanaša na značaj in značilnosti finančnega sveta. Vključuje poznavanje pravic in dolžnosti potrošnika na finančnem trgu in v splošnem finančnem okolju ter glavne posledice finančnih pogodb. Viri informacij in pravne ureditve so tudi teme, ki so pomembne za to vsebinsko področje. V najširšem pomenu besedne zveze finančni zemljevid vsebuje tudi razumevanje posledic sprememb gospodarskih pogojev in javne politike, kot so spremembe obrestnih mer, inflacija, obdavčenje ali socialna podpora. Naloge na tem vsebinskem področju preverjajo, ali dijaki:

- razumejo, da imajo posamezniki možnost izbire pri porabi denarja in varčevanju in da ima vsako dejanje lahko posledice za posameznika in družbo;

- razumejo, da imajo kupci in prodajalci pravice, kot je na primer pravica do odškodnine;

- razumejo, da imajo kupci in prodajalci dolžnosti, kot je na primer dolžnost, da podajo točne podatke, ko zaprosijo za finančne proizvode, in se zavedajo posledic, če tega ne storijo;

- prepoznajo pomen pravnih dokumentov pri nakupu finančnih proizvodov ali storitev in pomen razumevanja vsebine;

- vedo, koga vprašati za nasvet, ko kupujejo finančne proizvode, in kam se lahko obrnejo po pomoč v zvezi s finančnimi zadevami;

- vedo, kateri ponudniki so vredni zaupanja in kateri proizvodi in storitve so zaščiteni z zakonodajo ali zakoni o zaščiti potrošnikov;

- razumejo, kako imajo osebne navade, dejanja in odločitve vpliv na posameznika, skupnost, narod in svet;

- se zavedajo gospodarske klime in razumejo vpliv sprememb smernic, kot so reforme, ki se nanašajo na financiranje usposabljanja po koncu šolanja;

- razumejo, kako je lahko sposobnost povečanja premoženja ali dostopa do posojil odvisna od ekonomskih dejavnikov, kot so obrestne mere, inflacija in kreditna sposobnost;

- razumejo, da lahko vrsta zunanjih dejavnikov, kot so oglaševanje in pritisk vrstnikov, vpliva na finančne odločitve ljudi; in

- se zavedajo finančnih zločinov, kot so kraja identitete in prevare, in vedo, kako se pred njimi zavarovati.

Naslednji primer naloge dobro opisuje finančno prevaro. 
Primer št. 4: NAPAKA BANKE

Davidova banka je Zedbanka. David prejme tole elektronsko sporočilo.

Spoštovani komitent Zedbanke!

Na strežniku Zedbanke je prišlo do napake in vaši prijavni podatki za spletni dostop so izgubljeni.

To pomeni, da nimate dostopa do spletne banke.

Predvsem pa vaš račun ni več varen.

Prosimo, da kliknete na spodnjo povezavo in sledite navodilom za ponovno vzpostavitev dostopa. Prosili vas bomo, da navedete svoje podatke za poslovanje s spletno banko.

https://Zedbanka.com/

\section{zedbanka}

\section{Vprašanje: NAPAKA BANKE}

Kateri od teh predlogov bi bil dober nasvet za Davida?

Pri vsakem predlogu obkroži "Da" ali "Ne".

\begin{tabular}{|l|c|}
\hline \multicolumn{1}{|c|}{ Predlog } & $\begin{array}{c}\text { Je ta predlog dober nasvet } \\
\text { za Davida? }\end{array}$ \\
\hline $\begin{array}{l}\text { Naj odgovori na elektronsko sporočilo in navede svoje } \\
\text { podatke za poslovanje s spletno banko. }\end{array}$ & $\mathrm{Da} / \mathrm{Ne}$ \\
\hline $\begin{array}{l}\text { Naj odgovori na elektronsko sporočilo in prosi za več } \\
\text { podatkov. }\end{array}$ & $\mathrm{Da} / \mathrm{Ne}$ \\
\hline $\begin{array}{l}\text { Naj pokliče v svojo banko in se pozanima o } \\
\text { elektronskem sporočilu. }\end{array}$ & $\mathrm{Da} / \mathrm{Ne}$ \\
\hline $\begin{array}{l}\text { Če je povezava enaka kot spletni naslov njegove } \\
\text { banke, naj klikne na povezavo in sledi navodilom. }\end{array}$ & $\mathrm{Da} / \mathrm{Ne}$ \\
\hline
\end{tabular}


Spletno bančništvo je del širšega finančnega zemljevida, $s$ katerim se bodo dijaki slej ko prej srečali in v katerem se bodo lahko soočili s tovrstno goljufijo. S pomočjo zgoraj navedene naloge smo ugotavljali, ali se znajo dijaki v tovrstnih primerih primerno zaščititi. V okviru naloge so morali primerno odgovoriti na elektronsko sporočilo, ki je bilo finančna prevara. Potrebno je bilo ovrednotiti predstavljene opcije in prepoznati, da je primeren le drugi predlog. V predraziskavi je na to vprašanje pravilno odgovorilo le $40 \%$ vseh sodelujočih dijakov.

\section{Proces}

Kategorije procesov pri ugotavljanju finančne pismenosti se nanašajo na kognitivne procese. Uporabljamo jih pri opisu učenčevih sposobnosti, ki so potrebne, da prepozna in uporabi koncepte, pomembne za to področje, in razume, utemelji, oceni in predlaga rešitve. Pri finančni pismenosti v raziskavi PISA so opredeljeni štirje procesi: prepoznavanje finančnih podatkov, razčlenjevanje podatkov znotraj finančnega konteksta, vrednotenje finančnih vprašanj in uporaba finančnega znanja in razumevanja.

Medtem ko glagoli, uporabljeni tukaj, spominjajo na Bloomovo taksonomijo (Bloom, 1956), je pomembna razlika $v$ tem, da procesi v konstruktu finančne pismenosti niso predstavljeni kot hierarhija veščin, temveč kot vzporedni kognitivni pristopi, ki so vsi del repertoarja finančno pismenega posameznika. Vrstni red, v katerem so procesi predstavljeni tu, je tipično sosledje miselnih procesov in dejavnosti, torej procesi niso predstavljeni glede na stopnjo zahtevnosti ali izziva. Hkrati se zavedamo, da so razmišljanje, odločitve in dejanja, povezani z denarjem, največkrat odvisni od rekurzivne in interaktivne mešanice procesov, ki jih tu opisujemo. Za namen ocenjevanja vsako nalogo spremlja ime tistega procesa, ki je najbolj pomemben za njeno reševanje.

\section{Prepoznavanje finančnih podatkov}

Ta proces je uporabljen, ko posameznik išče in dostopa do virov finančnih podatkov, jih identificira in ugotavlja njihov pomen. V raziskavi PISA 2012 so podatki podani v obliki tiskanega besedila, kot so pogodbe, oglasi, grafi, tabele, obrazci in navodila. Pri tipični nalogi mora dijak prepoznati značilnosti računa ali pa ugotoviti stanje na bančnem izpisku. Pri zahtevnejši nalogi mora pregledati pogodbo, ki vsebuje zapletene pravne izraze, in poiskati informacijo, ki pojasni posledice neplačevanja obrokov posojila. To procesno kategorijo uporabi tudi v nalogi, ki vključuje prepoznavanje finančnega izrazoslovja. Prepoznati mora na primer besedo inflacija kot izraz, ki pomeni dviganje cen skozi čas. 
Tukaj navajamo primer naloge, katere cilj je ugotavljanje sposobnosti identifikacije in interpretacije finančnih informacij is-letnikov.

Primer št. 5: PLAČILNA LISTA ZAPOSLENEGA

Jani plačo vsak mesec nakažejo na njen bančni račun. To je Janina plačilna lista za julij.

\begin{tabular}{|lr|}
\hline PLAČILNA LISTA ZAPOSLENEGA: Jana Državljan \\
Delovno mesto: poslovodja & $01 .-31$. julij \\
Bruto plača & 2800 zedov \\
Odbitki & 300 zedov \\
Neto plača & 2500 zedov \\
& \\
Bruto plača do tega datuma v tem letu & 19600 zedov \\
\hline
\end{tabular}

\section{6. vprašanje: PLAČILNA LISTA}

Koliko denarja je Janin delodajalec nakazal na njen bančni račun 31. julija?
A 300 zedov.
B 2500 zedov.
C 2800 zedov.
D 19600 zedov.

Pri tem vprašanju so morali dijaki prepoznatifinančen podatek na dokaj enostavni plačilni listi zaposlenega. Pravilen odgovor, tj. 2500 zedov, je v predraziskavi izbralo le malo več kot $50 \%$ sodelujočih dijakov. 
Primer št. 6: DELNICE

Spodnji graf prikazuje ceno delnice podjetja Bogatin v 12-mesečnem obdobju.

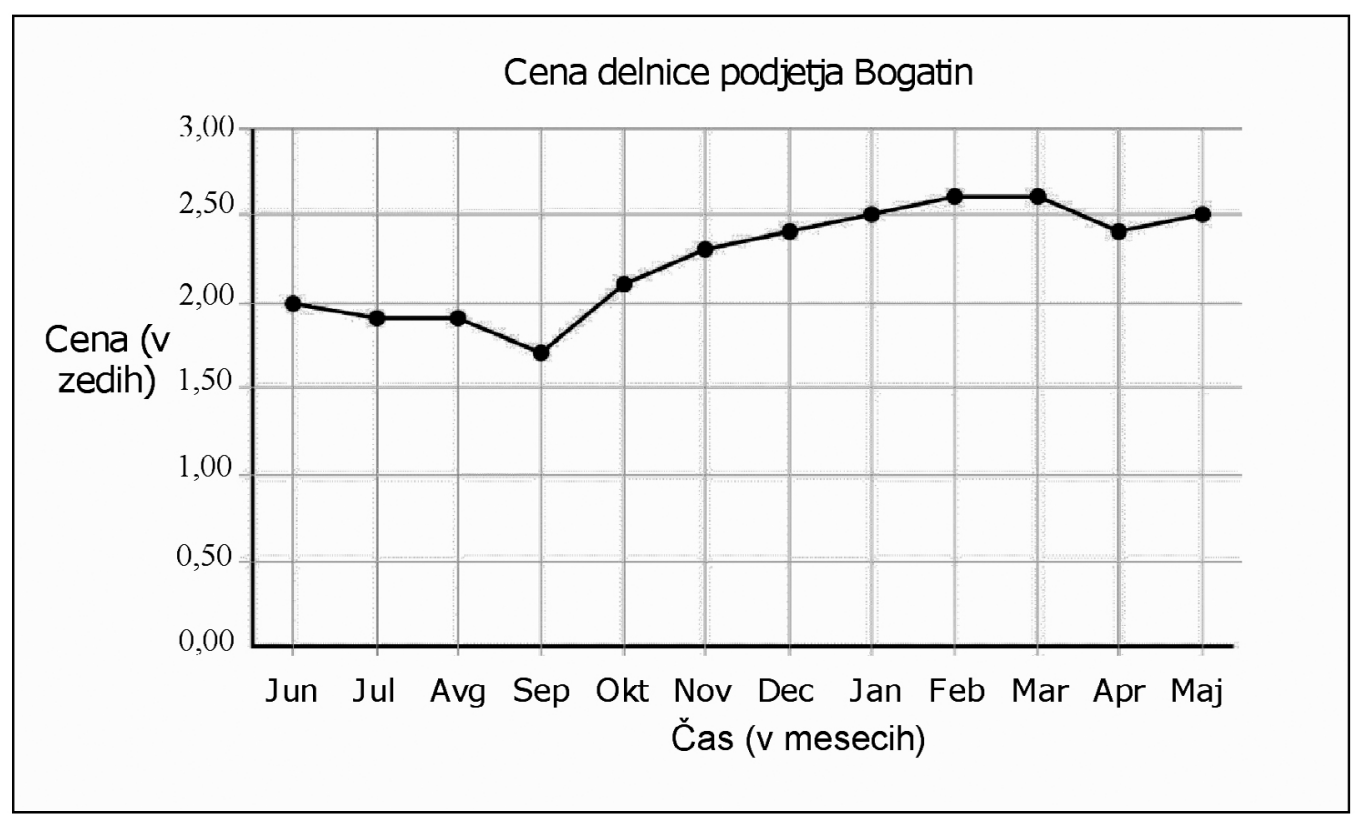

Vprašanje: DELNICE

Katere trditve o grafu držijo?

Pri vsaki trditvi obkroži "Drži” ali "Ne drži".

\begin{tabular}{|l|c|}
\hline \multicolumn{1}{|c|}{ Trditev } & Ali ta trditev drži ali ne drži? \\
\hline $\begin{array}{l}\text { Najboljši mesec za nakup delnic je bil } \\
\text { september. }\end{array}$ & Drži / Ne drži \\
\hline $\begin{array}{l}\text { Cena delnice se je med letom povečala } \\
\text { za približno 50\%. }\end{array}$ & Drži / Ne drži \\
\hline
\end{tabular}


Razčlenjevanje podatkov znotraj finančnega konteksta

Ta proces pokriva obsežno področje kognitivnih aktivnosti, ki se uporabljajo v finančnih kontekstih, med drugim interpretiranje, primerjanje in iskanje nasprotij, sintetiziranje in ekstrapoliranje podatkov, ki so na voljo. To področje vključuje prepoznavanje nečesa, kar na prvi pogled ni (eksplicitno) - identificiranje osnovnih predpostavk ali implikacij v finančnem kontekstu. Naloga lahko na primer vključuje primerjanje pogojev, ki jih v pogodbah ponujajo različni ponudniki mobilnih storitev, ali pa ugotavljanje, ali oglas za posojilo vsebuje pogoje, ki niso napisani v oglasu. Primer tovrstne naloge je prikazan spodaj.

Navedena naloga od dijakov zahteva razćlenitev podatkov znotraj finančnega konte$k s t a$, pri čemer morajo upoštevati informacijo v grafu, ki prikazuje spremembo v ceni delnice v I 2-mesečnem obdobju. S pomočjo te naloge ugotavljamo, ali dijak razume, da je treba delnice kupiti, ko je cena le-teh nizka ( $v$ tem primeru septembra). V naslednjem koraku pa nas zanima, ali zna dijak pravilno prepoznati dvig $\mathrm{v}$ cenah delnic in izračunati odstotno spremembo skozi čas. V predraziskavi je na to vprašanje šravilno odgovorilo le malo

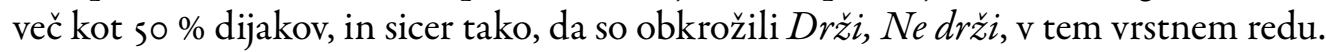

\section{Vrednotenje finančnih vprašanj}

$\mathrm{V}$ tem procesu se osredotočamo na prepoznavanje ali sestavljanje finančnih utemeljitev in razlag, ki ju črpamo iz finančnega znanja in razumevanja, uporabljenega v specifičnih kontekstih.

Proces vrednotenja finančnih vprašanj vključuje kognitivne aktivnosti, kot so razlaga, ocenjevanje in posploševanje. Pri tem procesu je pomembno kritično razmišljanje, pri čemer morajo dijaki uporabiti znanje, logično razmišljanje in zdravorazumske obrazložitve, da osmislijo in oblikujejo mnenje o finančnem problemu. Podatki, ki so potrebni za spopadanje $s$ tako nalogo, so delno na voljo v besedilu ali sliki, v priloženi nalogi, dijaki pa morajo te podatke povezati $s$ svojim znanjem in $\mathrm{z}$ razumevanjem. V kontekstu raziskave PISA se predvideva, da je vsak podatek, ki je potreben za razumevanje problema, že del izkušenj I 5 -letnikov. Tako se na primer predvideva, da so se Is-letniki sposobni poistovetiti (s kom ali čim?) ali si predstavljati izkušnjo, ko si želimo nekaj, kar ni nujno potrebno (kot so na primer novi zvočniki). Naloga, ki temelji na tem scenariju, bi lahko spraševala po dejavnikih, ki jih je treba upoštevati, ko se odločamo o relativnih finančnih prednostih takojšnega ali odloženega nakupa $\mathrm{v}$ določenih finančnih okoliščinah.

Naslednje vprašanje temelji na enakem uvodnem besedilu naloge kot v I. primeru (NA TRŽNICI), od dijakov pa zahteva, da dano informacijo ovrednotijo v skladu s svo- 
jim poprejšnjim, splošnim znanjem, ki naj bi ga črpali iz vsakodnevnih, življenjskih situacij.

\section{Primer št. 7: NA TRŽNICI (2)}

\section{Vprašanje: NA TRŽNICI}

Za nekatere ljudi je lahko nakup zaboja paradižnikov slaba finančna odločitev.

Pojasni, zakaj.

Namen tega vprašanja je, da dijaki prepoznajo, da nakup zaboja paradižnikov lahko predstavlja izgubo na finančnem področju ali da je to nakup, ki si ga nekateri v danem trenutku niti ne morejo privoščiti. Dijak prejme kodo za pravilen odgovor, če dano situacijo ovrednoti in pojasni v smislu, da nakup večjega števila paradižnikov po nižji ceni ni vedno dobra finančna odločitev. Tukaj navajamo nekaj primerov pravilnih odgovorov, ki so lahko različni:

- Paradižniki labko zgnijejo, preden vse porabis.

- Mogoče ne potrebuješ so kg paradižnikov.

Naslednji tip odgovora, za katerega bi dijak prav tako prejel kodo za pravilen odgovor, je naslednji:

- Porabiti bi moral 22 zedov (namesto 2,75 ali 5,5o za I ali $2 \mathrm{~kg}$ ) in mogoče nimaš toliko denarja.

- Da bi labko kupil zaboj paradižnikov, bi mogoče moral preživeti brez česa drugega, kar potrebuješ.

V predraziskavi PISA 2012 je na navedeno vprašanje pravilno odgovorilo preko $80 \%$ dijakov.

Naslednja naloga pa predstavlja primer zahtevnejšega vprašanja znotraj sklopa vrednotenja finančnib vprašanj. 
Ga. Jelen ima pri prvi Zedbanki 8000 zedov posojila. Letna obrestna mera za to posojilo je 15 $\%$. Vsak mesec odplača obrok, ki znaša 150 zedov.

Po enem letu ga. Jelen dolguje še 7400 zedov.

Druga finančna družba, ki se imenuje Zedkrona, je ge. Jelen ponudila posojilo v znesku 10 000 zedov z letno obrestno mero $13 \%$. Tudi tu bi na mesec odplačevala obroke po 150 zedov.

\section{Vprašanje: NOVA PONUDBA}

Navedi eno možno negativno finančno posledico za go. Jelen, če bo najela posojilo pri Zedkroni?

Navedeno vprašanje od dijakov zahteva, da ovrednotijo in razmislijo o posledicah spreminjanja pogojev posojila - kontekst, ki je Is-letnikom manj poznan kot prej opisana situacija na tržnici. Pri tem vprašanju so za razliko od prejšnjega vse potrebne informacije navedene v nalogi, a mora dijak za pravilen odgovor najprej prepoznati bistveno informacijo, nato pa predvideti in oceniti posledice, ki lahko določenemu dejanju sledijo. Kategorija pravilnega odgovora pri tem vprašanju zajema zelo različne odgovore. V predraziskavi je bil najpogostejši izmed njih ta, da bi imela na ta način ga. Jelen še več dolga. Vendar bi bil enako sprejemljiv odgovor tudi tak, ki bi se nanašal na specifične pogoje posojila: skupne obresti bodo na koncu večje, čas odplačevanja kredita bo daljši, ob menjavi banke lahko zaradi tega nastopijo dodatni stroški ipd. V predraziskavi je na obravnavano vprašanje pravilno odgovorilo približno $40 \%$ vseh sodelujočih dijakov.

Glede na kognitivni proces, ki ga naloga zajema, v kategorijo vrednotenja finančnih vprašanj uvrščamo tudi nalogo iz primera št. 2, stran 38 , ODLOČITEV GLEDE IZDATKOV.

\section{Uporaba finančnega znanja in razumevanja}

Četrti proces uporabi izraz iz opredelitve finančne pismenosti: »... da ljudje uporabijo to finančno znanje in razumevanje ...«. Osredotoča se na učinkovita dejanja v finančnem okolju s pomočjo uporabe poznavanja finančnih proizvodov in kontekstov ter razumevanja finančnih konceptov. Ta proces je opazen v nalogah, ki vključujejo računanje in reševanje problemov, velikokrat pa je treba upoštevati veliko različnih pogojev. Primer naloge te vrste je računanje obresti za dveletno posojilo. Ta proces je viden tudi v nalogah, ki 
zahtevajo uporabo znanja v specifičnem kontekstu. V nalogi mora dijak na primer ugotoviti, ali bo kupna moč skozi čas narasla ali upadla, ko se cene spreminjajo z dano hitrostjo. $\mathrm{V}$ tem primeru mora dijak uporabiti znanje o inflaciji.

Kot primer naloge, ki od dijaka zahteva uporabo finančnega znanja in razumevanja, navajamo nalogo spodaj. $\mathrm{V}$ okviru te naloge morajo dijaki preučiti niz pogojev in ovir $\mathrm{v}$ okviru načrtovanja prihajajočih stroškov - glede na informacijo o tedenskem zaslužku morajo izračunati, koliko časa morajo varčevati za počitnice. Pravilen odgovor je 6 tednov. $\mathrm{V}$ predraziskavi je na to vprašanje pravilno odgovorilo manj kot $50 \%$ dijakov.

\section{Primer št. 9: DENAR ZA POTOVANJE}

Nataša dela v restavraciji 3 večere na teden.

Vsak večer dela 4 ure in zasluži 10 zedov na uro.

Nataša z napitninami vsak teden zasluži še 80 zedov.

Nataša privarčuje natanko polovico vsega denarja, ki ga zasluži vsak teden.

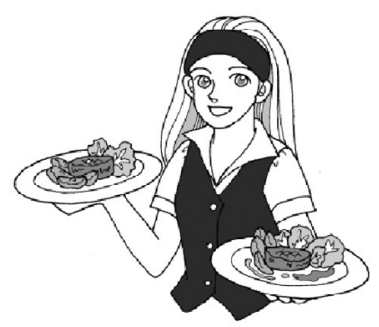

\section{Vprašanje: DENAR ZA POTOVANJE}

Nataša bi rada prihranila 600 zedov za počitnice.

Koliko tednov bo trajalo, da bo Nataša prihranila 600 zedov?

Število tednov:

\section{Kontekst}

Ko za ocenjevanje finančne pismenosti sestavljamo izhodišča in naloge, ki jih bomo razvili in izbrali na podlagi tega okvira, je veliko pozornosti namenjene širini izbora kontekstov, v katerih je pismenost uporabljena. Odločitve o finančnih problemih so pogosto odvisne od kontekstov ali situacij, v katerih se problemi pojavljajo. Ko postavimo naloge $\mathrm{v}$ različne kontekste, ocenjevanje ponuja možnost povezovanja $\mathrm{z}$ najrazličnejšimi posameznikovimi interesi in $\mathrm{z}$ različnimi situacijami, $\mathrm{v}$ katerih mora posameznik funkcionirati $\mathrm{v}$ enaindvajsetem stoletju.

Nekatere situacije so bližje Is-letnikom kot druge. V raziskavi PISA so ocenjevalne naloge postavljene v vsakdanje situacije, ki lahko vključujejo šolski kontekst, niso pa ve- 
dno vezane nanj. Poudarek je lahko na posamezniku, družini ali skupini vrstnikov, na širši skupnosti ali pa širše, na globalnemu kontekstu.

Skupina strokovnjakov je kot izhodišče vzela kontekste, ki so bili uporabljeni v okviru Programa za mednarodno ocenjevanje pismenosti odraslih (PIAAC): izobraževalni in delovni, družinski, osebni ter družbeni (OECD, 2009b).

\section{Izobraževalni in delouni kontekst}

Izobraževalni in delovni kontekst je zelo pomemben za mlade ljudi. Veliko dijakov v raziskavi PISA bo nadaljevalo šolanje in usposabljanje, mnogi drugi I 5 -letniki se bodo $\mathrm{v}$ letu ali dveh pridružili delovni sili, nekaj pa jih že ima občasno zaposlitev po pouku. Zato je trenutni in srednjeročni delovni kontekst pomemben tudi za dijake v raziskavi PISA. Skoraj vsi I5-letniki bodo slej ko prej začeli razmišljati o finančnih zadevah, ki se tičejo izobrazbe ali dela, bodisi bodo trošili prislužen denar, razmišljali o možnostih prihodnje izobrazbe ali načrtovali delovno dobo.

Tipične naloge v tem kontekstu vključujejo razumevanje plačilne liste, načrtovanje varčevanja za terciarno izobraževanje, raziskovanje prednosti in tveganj najemanja posojila za študij ter sodelovanja pri varčevalnih načrtih na delovnem mestu.

\section{Domači in družinski kontekst}

Dom in družina vključuje finančne teme, ki se tičejo gospodinjskih stroškov. Gospodinjstvo v okviru družine je najpogostejše okolje za I5-letnike, toda ta kategorija obsega tudi okolja, ki ne temeljijo na družinskih razmerjih, kot je na primer skupno bivanje mladih ljudi kmalu zatem, ko zapustijo družinski dom. Naloge v tem kontekstu lahko vključujejo nakup gospodinjskih potrebščin ali hrane, zapisovanje porabe in načrtovanje družinskih dogodkov. Tudi odločitve o proračunu in prednostnih nakupih najdemo v tem kontekstu.

\section{Osebni kontekst}

Osebni kontekst je pomemben za osebne finance I5-letnika, saj veliko odločitev posameznik sprejme zgolj zaradi osebne koristi ali zadovoljstva, obstaja pa tudi veliko dolžnosti, ki jih s tem nosi. Odločitve, ki jih posameznik sprejema in spadajo v ta kontekst, vključujejo izbiro proizvodov in storitev za osebno porabo, kot so na primer oblačila, pripomočki za osebno nego in striženje las, ali pa nakup potrošnih dobrin, kot sta elektronska ali športna oprema, pa tudi obveznosti, kot je plačevanje sezonskih kart ali članarine $\mathrm{v}$ fitnes klubu. Te odločitve vključujejo nujne osebne potrebe, kot tudi prosti čas in rekreacijo. Čeprav na odločitve posameznika lahko vplivata družina ali družba, nosi posame- 
Primer št. 10: NOVA BANČNA KARTICA

Liza živi v Zedlandiji. Dobi novo bančno kartico.

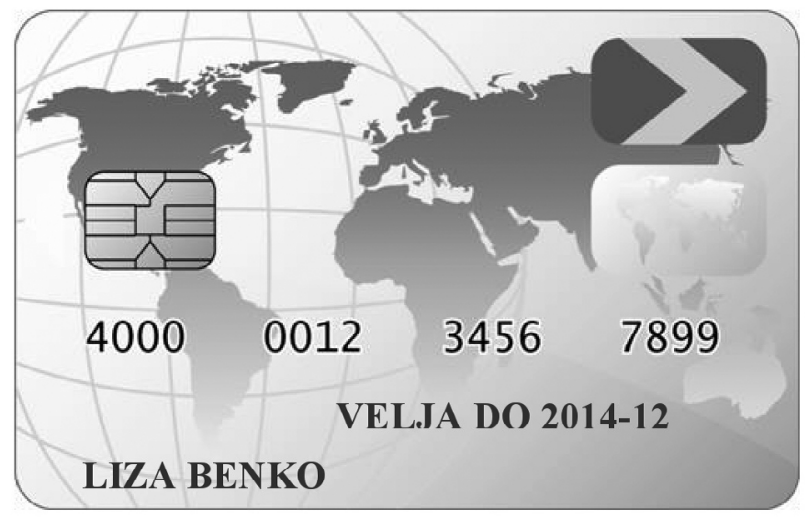

Vprašanje: NOVA BANČNA KARTICA

Naslednji dan prejme Liza osebno identifikacijsko številko (PIN kodo) za svojo bančno kartico.

Kaj naj Liza stori s PIN kodo?

A PIN kodo naj zapiše na listek in ga spravi v denarnico.

B PIN kodo naj pove svojim prijateljem.

C PIN kodo naj zapiše na hrbtno stran kartice.

D PIN kodo naj si zapomni.

znik sam pravno odgovornost za te odločitve, ko odpre bančni račun ali pa najame kredit. Ta kontekst torej vključuje pogodbene teme, ki so del dogodkov, kot so odprtje bančnega računa, nakup potrošnih dobrin, plačevanje rekreacijskih dejavnosti in poslovanje z ustreznim finančnimi službami, ki so velikokrat povezane z večjimi potrošnimi dobrinami, kot so posojila in zavarovanja. Primer naloge, ki je postavljena v osebni kontekst I5-letnika, je naloga NOVA BANČNA KARTICA.

$S$ pomočjo te naloge smo ugotavljali dijakovo razumevanje osebne odgovornosti in vzdrževanja zasebnosti pri uporabi elektronskega bančništva. Dijak je moral izmed štirih navedenih odgovorov pravilno prepoznati možnost, ki predstavlja najboljši način ravna- 
nja $\mathrm{z}$ bančno kartico. $\mathrm{V}$ predraziskavi je na to vprašanje pravilno (odgovor $\mathrm{D}$ ) odgovorilo malo čez $90 \%$ dijakov.

\section{Družbeni kontekst}

Za okolje, v katerem mladi ljudje živijo, so značilne nenehne spremembe, kompleksnost in medsebojna odvisnost. Globalizacija ustvarja nove oblike medsebojne odvisnosti, pri čemer so dejanja podvržena ekonomskim vplivom in imajo njihove posledice vpliv ne samo na posameznika, temveč tudi na lokalno skupnost. Medtem ko se jedro finančne pismenosti osredotoča na osebne finance, je v družbenem kontekstu jasno, da ne moremo ločiti posameznikovega finančnega blagostanja od družbenega finančnega blagostanja. Osebno finančno blagostanje vpliva na lokalno skupnost, narod in celo globalne aktivnosti, hkrati pa lokalna skupnost, narod in globalne aktivnosti vplivajo na posameznikovo finančno blagostanje. Finančna pismenost v tem kontekstu vključuje stvari, kot so informiranje o potrošnikovih pravicah in dolžnostih, razumevanje smisla obdavčitve in finančnih bremenitev lokalnih vlad, ozaveščenost o poslovnih interesih in upoštevanje vloge potrošnikove nakupne moči. Vključuje tudi finančne odločitve, kot je darovanje denarja neprofitnim organizacijam in dobrodelnim ustanovam.

\section{Drugi dejavniki finančne pismenosti}

V okviru ugotavljanja finančne pismenosti v raziskavi PISA 2012 so se strokovnjaki s pomočjo dodatnih vprašanj ob koncu delovnih zvezkov odločili ugotavljati tudi štiri nekognitivne dejavnike, ki so pomembni pri razumevanju stopnje finančne pismenosti, ki jo dijak dosega. Le-ti se navezujejo na odnos do finančnih zadev ter vedenje v omenjenih situacijah in so naslednji: dostop do informacij in finančnega izobraževanja, dostop do denarja in finančnih proizvodov, odnos do finanćnih zadev in samozavest $v$ omenjenih situacijah ter vedenjski vzorci trošenja in varčevanja.

\section{Dostop do informacij in finančnega izobraževanja}

Dijakom je na voljo veliko virov finančnih informacij: prijatelji, starši in drugi družinski člani, mediji ter finančne ustanove. Dobro je vedeti, kateri viri informacij se najbolj pogosto uporabljajo, in ugotoviti, ali so višje stopnje finančne pismenosti povezane $z$ dostopnostjo določenih virov informacij. Tudi oblikovalci politike lahko uporabijo te podatke, da ugotovijo, kako dobro ljudje sprejemajo informacije o finančnih temah in na katero področje naj usmerijo nove intervencije.

Izobraževanje in usposabljanje, ki so ga deležni dijaki, je znotraj držav in med državami različno. Informacije o obsegu povezanosti med stopnjo finančne pismenosti in finanč- 
nim izobraževanjem v šolah in zunaj njih so še posebno uporabne pri oblikovanju programov za izboljšanje finančne pismenosti.

\section{Dostop do denarja in finančnih proizvodov}

Pričakujemo lahko, da se tisti dijaki, ki imajo več osebnih izkušenj s finančnimi zadevami, bolje odrežejo pri kognitivnem ocenjevanju finančne pismenosti. Verjetneje je, da tisti dijaki, ki redno sprejemajo odločitve o upravljanju svojega denarja, vedo več o finančnih zadevah kot dijaki, ki ne sprejemajo teh odločitev, čeprav dijakov o teh zadevah nikoli nihče ni formalno izobraževal. Te izkušnje lahko izvirajo iz plačanega dela, uporabe finančnih proizvodov, kot so kreditne in debetne kartice, ali pa iz poslovanja z bančnim sistemom. Ključno vprašanje za oblikovanje politike na tem področju je: »Koliko vsakdanje izkušnje iz sveta financ vplivajo na finančno pismenost mladih ljudi? «

\section{Odnos do finančnih zadev in samozavest v omenjenih situacijah}

Odnos do finančnih zadev je pomemben del finančne pismenosti. Še več, osebne preference pomembno določajo finančno vedenje in lahko vzajemno delujejo s finančno pismenostjo. Predpostavlja se, da bodo raziskave s področja vedenjske psihologije pokazale zanimive rezultate glede finančne pismenosti in posredovale boljše podatke oblikovalcem politike, ki poskušajo izboljšati učinkovitost programov. Predpostavlja se, da finančno vedenje v veliki meri določajo naslednji dejavniki:

- $\quad$ sprejemanje tveganja - pripravljenost sprejeti možnost izgube, da dosežeš večjo korist (Barsky et al., 1997; Holt in Laury, 2002);

- časovna občutljivost - pripravljenost, da zamenjaš takojšnjo zadovoljitev za poznejšo večjo korist (Barsky et al., 1997; Holt in Laury, 2002);

- lokus nadzora - prepričanje, da ima posameznik nadzor nad zadevami, ki se ga tičejo (Rotter, 1966);

- fatalizem - prepričanje, da se bodo slabe stvari verjetneje zgodile posamezniku kot pa drugim; in

- $\quad$ splošna samozavest pri finančnih zadevah - prepričanje, da ima posameznik dovolj znanja in razumevanja, da uspešno izvrši finančne transakcije.

\section{Vedenjski vzorci trošenja in varčevanja}

Medtem ko s pomočjo nalog v kognitivnem delu ugotavljamo sposobnost dijakov, da sprejmejo določeno odločitev o porabi denarja ali varčevanju, je pomembno tudi to, da imamo vsaj nekaj podatkov o tem, kakšno je njihovo vedenje, torej o tem, kako dijaki var- 
čujejo in trošijo denar. To nam omogoča primerjavo finančnega vedenja 15 -letnikov in njihovih rezultatov na testu finančne pismenosti. 


\section{Finančna pismenost $v$ povezavi $z$ matematično in bralno pismenostjo}

\section{Veščine računanja}

Določena stopnja matematične pismenosti je nujen pogoj za finančno pismenost. Huston (2010) meni, da posameznikove težave $\mathrm{z}$ veščinami računanja prav gotovo vplivajo na njegovo/njeno finančno pismenost. Toda orodja, ki so na voljo (npr. žepni kalkulator), lahko nadomestijo te pomanjkljivosti; zato se je pri merjenju finančne pismenosti bolj pomembno osredotočati na informacijo, ki je neposredno povezana $\mathrm{z}$ uspešnim upravljanjem osebnih financ, kot pa na veščine računanja. Zato testi, ki ocenjujejo finančno pismenost, pogosteje vključujejo naloge, ki imajo vidik matematične pismenosti, čeprav ta vidik ni $\mathrm{v}$ žarišču merjenja. Lusardi in drugi (20I0) so poročali, da so tri vprašanja s področja finančne pismenosti v Nacionalni longitudinalni raziskavi mladine, opraviljeni leta 1997 v ZDA, dobro pokazala razliko med dobro in slabo finančno pismenostjo anketirancev. Dve izmed treh vprašanj, ki sta se nanašali na obrestno mero in inflacijo, sta zahtevali nekaj osnovnega znanja s področja matematične pismenosti. Sposobnosti, ki so se pokazale kot pomembno povezane z matematičnim znanjem, so bile: občutek za števila, poznavanje različnih načinov predstavitve števil in veščine računanja na pamet ter ocenjevanje vrednosti in verjetnosti izračuna.

$\mathrm{Na}$ drugi strani pa so področja, kjer se vsebine matematične in finančne pismenosti ne prekrivajo. Matematična pismenost v raziskavi PISA 2012 pokriva štiri vsebinska področja: spremenljivke in odnose, like in telesa, količino ter verjetnost in delo s podatki. Od teh se le količina neposredno prekriva z vsebino finančne pismenosti. Na primer, namesto vsebinskega sklopa verjetnost in delo s podatki pri matematični pismenosti, ki od dijakov zahteva uporabo verjetnostnega izračuna in statistike, je pri finančni pismenosti uporabljen sklop tveganje in dobiček. Razlika je v tem, da je pri slednjem potrebna le splo- 
šna (nenumerična) presoja o tem, da na posameznikovo finančno blagostanje lahko vpliva tudi naključje, in zavedanje, da so finančni proizvodi povezani med seboj, ter dejanja, ki nas lahko zaščitijo pred izgubo. Slika 3 predstavlja odnos med vsebino matematične in finančne pismenosti v raziskavi PISA 2012.

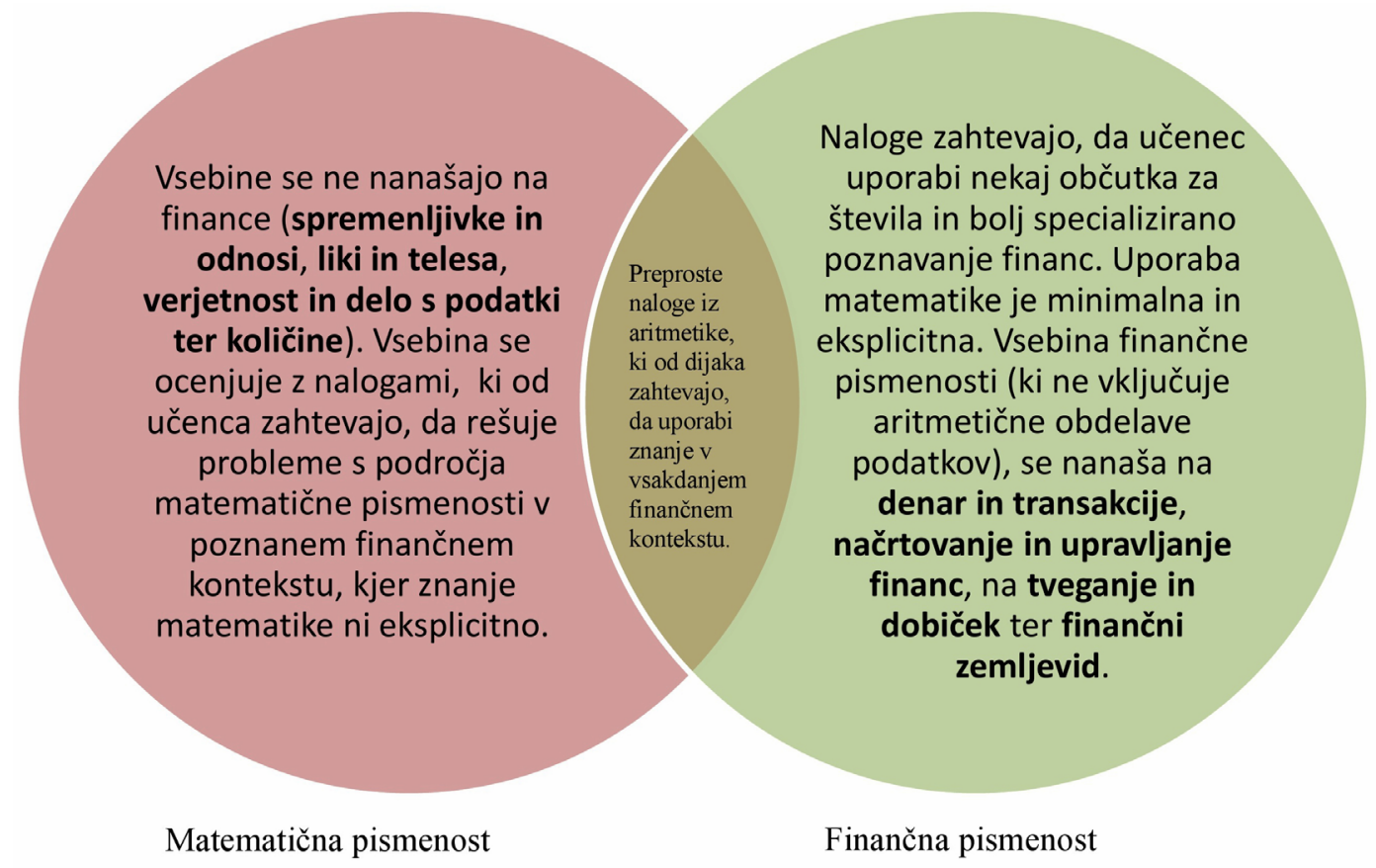

Slika 3: Odnos med vsebino finančne in matematične pismenosti v raziskavi PISA 20 I2

Nekaj nalog je tudi v preseku obeh krogov. Pri ocenjevanju finančne pismenosti pričakujemo od dijakov osnovno aritmetiko, in sicer štiri operacije (seštevanje, odštevanje, množenje in deljenje) s celimi števili, decimalnimi števili in odstotki. Taka aritmetika se pojavlja kot neločljivi del konteksta finančne pismenosti in omogoča uporabo in prikaz finančnega znanja s področja finančne pismenosti, naloge pa ne zahtevajo poznavanja finančnih formul (kar zahteva znanje algebre). Potreba po računanju je pri ocenjevanju zanemarljiva; naloge so sestavljene tako, da se izognemo potrebi po daljšem ali ponavljajočem se računanju. Dijaki smejo uporabljati tudi žepne kalkulatorje, a uspešnost pri reševanju nalog ni odvisna od uporabe le-teh. 


\section{Branje in besedišče}

Da bi bila pri reševanju nalog iz finančne pismenosti potrebna stopnja bralne pismenosti kar najbolj zanemarljiva, je stimulativno gradivo (in besedilo nalog) oblikovano tako, da je kar najbolj jasno, preprosto in kratko. V nekaterih primerih pa lahko uvodno besedilo namenoma vsebuje zahtevno besedišče. Sposobnosti branja in razlaganja besedišča finančnih dokumentov sta del finančne pismenosti.

Besedilo nalog tudi ne zajema uporabe preveč strokovne terminologije s področja finančnih zadev. Skupina strokovnjakov je svetovala o izboru izrazov, za katere lahko upravičeno pričakujemo, da jih is-letniki razumejo. Nekateri izmed teh izrazov so tudi poudarjeni v samih nalogah. 



\section{Naloge iz finančne pismenosti}

V nadaljevanju predstavljamo naloge $s$ področja finančne pismenosti, ki so bile uporabljene v predraziskavi PISA 2012 in so bile za glavni zajem podatkov iz različnih razlogov izločene, saj rezultati niso omogočali mednarodne primerljivosti (npr., naloga se ni pokazala kot enako zahtevna za vse sodelujoče države, po vsebini ni bila enako dobro razumljiva I5-letnikom v vseh sodelujočih državah ipd.).

Pri vsaki nalogi najprej navajamo uvodno besedilo naloge, nato vprašanja, ki sledijo, temu pa sledi še kodirna shema pravilnih in nepravilnih odgovorov za določeno vprašanje. Pri vsaki nalogi navajamo tudi vsebino, proces in kontekst, $v$ katerega se naloga uvršča, ter del dijakov, ki so na posamezno vprašanje v predraziskavi odgovorili pravilno. 


\section{ODLOČITEV GLEDE IZDATKOV}

Cvetka in njene prijateljice najamejo hišo.

Vse so zaposlene že dva meseca.

Nimajo nobenih prihrankov.

Plačane so enkrat mesečno in pravkar so prejele plačo.

Naredile so seznam stvari, ki jih je treba narediti.

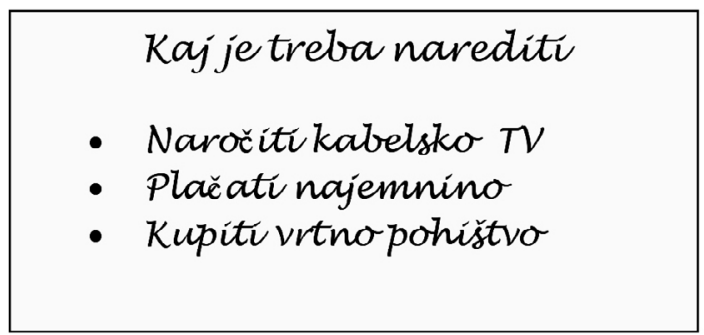

\section{1. vprašanje: ODLOČITEV GLEDE IZDATKOV}

Katerim od nalog na seznamu se bodo morale Cvetka in njene prijateljice verjetno kmalu posvetiti?

Pri vsaki nalogi obkroži "Da" ali "Ne".

\begin{tabular}{|l|c|}
\hline \multicolumn{1}{|c|}{ Naloga } & $\begin{array}{c}\text { Ali je verjetno, da se bo treba tej nalogi kmalu } \\
\text { posvetiti? }\end{array}$ \\
\hline Naročiti kabelsko TV & $\mathrm{Da} / \mathrm{Ne}$ \\
\hline Plačati najemnino & $\mathrm{Da} / \mathrm{Ne}$ \\
\hline Kupiti vrtno pohištvo & $\mathrm{Da} / \mathrm{Ne}$ \\
\hline
\end{tabular}




\section{ODLOČITEV GLEDE IZDATKOV: TOČKOVANJE I}

\section{NAMEN VPRAŠANJA:}

Opis: Prepoznati stvar, ki ji je treba dati prednost pri načrtovanju proračuna Vsebina: Načrtovanje in upravljanje financ

Proces: Vrednotenje finančnih vprašanj

Kontekst: Domači in družinski

Pravilen odgovor

Koda I: $\quad$ Trije pravilni odgovori: $\mathrm{Ne}, \mathrm{Da}, \mathrm{Ne}, \mathrm{v}$ tem vrstnem redu.

Nepravilen odgovor

Koda o: $\quad$ Manj kot trije pravilni odgovori.

Koda 9: $\quad$ Ni odgovora.

V predraziskavi PISA 2012 je na to vprašanje pravilno odgovorilo približno 75 \% dijakov iz vseh sodelujočih držav. 


\section{DENAR ZA POTOVANJE}

Nataša dela v restavraciji 3 večere na teden.

Vsak večer dela 4 ure in zasluži ıo zedov na uro.

Nataša z napitninami vsak teden zasluži še 80 zedov.

Nataša privarčuje natanko polovico vsega denarja, ki ga zasluži vsak teden.

\section{2. vprašanje: DENAR ZA POTOVANJE}

Nataša bi rada prihranila 600 zedov za počitnice.

Koliko tednov bo trajalo, da bo Nataša prihranila 600 zedov?

Število tednov:

\section{DENAR ZA POTOVANJE: TOČKOVANJE 2}

\section{NAMEN VPRAŠANJA:}

Opis: Izračunati čas, potreben, da se prihrani določen znesek

Vsebina: Načrtovanje in upravljanje financ

Proces: Uporaba finančnega znanja in razumevanja

Kontekst: Izobraževalni in delovni

\section{Pravilen odgovor}

Koda I: 6

$$
\text { - šest [Zapisano z besedo.] }
$$

Nepravilen odgovor

Code o: $\quad$ Drugi odgovori.

Koda 9: $\quad$ Ni odgovora.

V predraziskavi PISA 2012 je na to vprašanje pravilno odgovorilo manj kot $50 \%$ dijakov iz vseh sodelujočih držav. 


\section{NOVA PONUDBA}

Ga. Jelen ima pri Prvi Zedbanki 8000 zedov posojila. Letna obrestna mera za to posojilo je $15 \%$. Vsak mesec odplača obrok, ki znaša 150 zedov.

Po enem letu ga. Jelen dolguje še 7400 zedov.

Druga finančna družba, ki se imenuje Zedkrona, je ge. Jelen ponudila posojilo v znesku IO 000 zedov z letno obrestno mero I3 \%. Tudi tu bi na mesec odplačevala obroke po I50 zedov.

\section{3. vprašanje: NOVA PONUDBA}

Navedi eno možno negativno finančno posledico za go. Jelen, če bo najela posojilo pri Zedkroni?

\section{NOVA PONUDBA: TOČKOVANJE 3}

\section{NAMEN VPRAŠANJA:}

Opis: Prepoznati negativno posledico visokega posojila

Vsebina: Načrtovanje in upravljanje financ

Proces: Vrednotenje finančnih vprašanj

Kontekst: Osebni

Pravilen odgovor

Koda Ir: Omeni, da bi ga. Jelen imela več dolga.

- Dolgovala bi več denarja.

- Ne bi mogla nadzirati svojega trošenja denarja.

- Še bolj bi se zadolžila.

Koda I2: $\quad$ Omeni, da bi v celoti plačala več obresti.

- $13 \%$ od 10 ooo je več kot $15 \%$ od 8000 .

Koda I3: Omeni, da bi dlje odplačevala posojilo.

- Mogoče bi posojilo dlje odplačevala, ker je večje, obroki pa so enaki. 
Koda I4: Omeni možnost, da bi plačala stroške predčasnega odplačila pri PrviZedbanki. - Mogoče bi ji zaračunali penale, ker bi prej odplačala posojilo pri družbi Prvi Zedbanki.

Nepravilen odgovor

Koda ००: $\quad$ Drugi odgovori.

Koda 99: Ni odgovora.

$\mathrm{V}$ predraziskavi PISA 2012 je na to vprašanje pravilno odgovorilo približno $40 \%$ dijakov iz vseh sodelujočih držav. 
NA TRŽNICI

Paradižnike lahko kupiš na kilogram ali na zaboj.

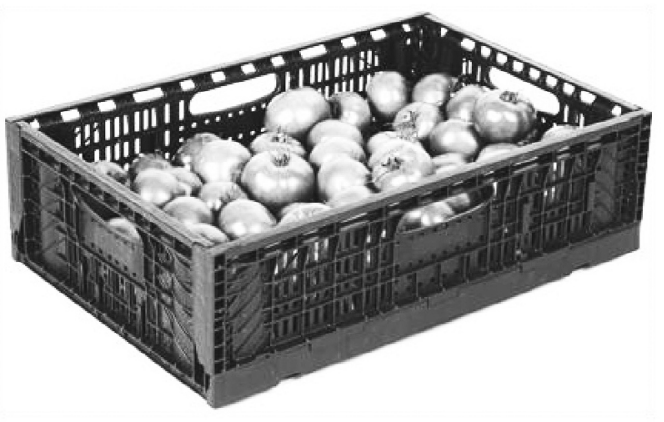

\section{2,75 zeda za kilogram}

\section{2 zedov za 10-kilogramski} zaboj

4. vprašanje: NA TRŽNICI

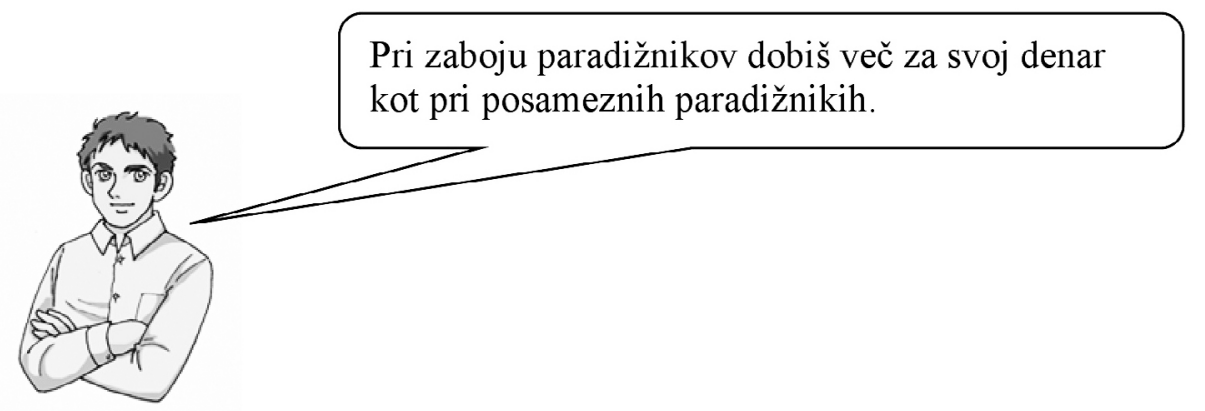

Navedi razlog, ki podpira to trditev. 
NA TRŽNICI: TOČKOVANJE 4

\section{NAMEN VPRAŠANJA:}

Opis: Prepoznati vrednost s primerjavo cen na enoto

Vsebina: Denar in transakcije

Proces: Razčlenjevanje podatkov znotraj finančnega konteksta

Kontekst: Domači in družinski

Pravilen odgovor

Koda I: $\quad$ Eksplicitno ali implicitno zapiše, da je cena za kilogram paradižnikov v zaboju nižja od cene za kilogram posameznih paradižnikov.

- Kgposameznihparadižnikovstane 2,75 zeda,kgparadižnikovvzaboju

pa samo 2,2 zeda.

- V zaboju stanejo samo 2,20 za kg.

- Ker bi ıo kg posameznih paradižnikov stalo 27,50 zeda.

- Dobiš več kg za vsak zed, ki ga plačaš.

- Posamezni paradižniki stanejo 2,75 za kg, paradižniki v zaboju pa

2,2 za kg.

- Cena na kg je nižja. [Sprejmemo posplošitev.]

- Cena na paradižnik je nižja. [Sprejmemo domnevo, da so paradižni ki enake velikosti.]

- Dobiš več paradižnika za zed. [Sprejmemo posplošitev.]

Nepravilen odgovor

Koda o: $\quad$ Drugo.

- Če kupiš zaboj, zmeraj dobiš več za svoj denar. [Brez pojasnila.]

- Dobiš več za manj. [Nejasno.]

- Boljše je kupovati velike količine.

- Cena za kilogram je različna. [Nenavede, daje cena za kilogram vzabo ju nižja.]

Koda 9: $\quad$ Ni odgovora.

V predraziskavi PISA 2012 je na to vprašanje pravilno odgovorilo približno $75 \%$ dijakov iz vseh sodelujočih držav. 


\section{NA TRŽNICI: TOČKOVANJE 5}

\section{5. vprašanje: NA TRŽNICI}

Za nekatere ljudi je lahko nakup zaboja paradižnikov slaba finančna odločitev.

Pojasni, zakaj

\section{NAMEN VPRAŠANJA:}

Opis: Ugotoviti, da je kupovanje velikih količin lahko potratno

Vsebina: Denar in transakcije

Proces: Vrednotenje finančnih vprašanj

Kontekst: Domači in družinski

\section{Pravilen odgovor}

Koda II: Omeni tratenje denarja, če ne potrebujemo večje količine paradižnikov.

- Paradižniki lahko zgnijejo, preden vse porabiš.

- Mogoče ne potrebuješ io kg paradižnikov.

- Tisti na dnu zaboja so mogoče pokvarjeni, torej po nepotrebnem za pravljaš denar.

Koda I2: $\quad$ Navede misel, da si nekateri ljudje ne morejo privoščiti višjega absolutnega stroška pri nakupu večjih količin.

- Mogoče si ne moreš privoščiti celega zaboja.

- Porabiti bi moral 22 zedov (namesto 2,75 ali 5,50 za I ali $2 \mathrm{~kg}$ ) in mo goče nimaš toliko denarja.

- Da bi lahko kupil zaboj paradižnikov, bi mogoče moral preživeti brez česa drugega, kar potrebuješ.

Nepravilen odgovor

Koda o०: Drugo.

- To ni pametno.

- Nekateri ljudje ne marajo paradižnika [Irelevantno.]

Koda 99: Ni odgovora.

V predraziskavi PISA 2012 je na to vprašanje pravilno odgovorilo več kot $80 \%$ dijakov iz vseh sodelujočih držav. 


\section{PLAČILNA LISTA}

Jani plačo vsak mesec nakažejo na njen bančni račun. To je Janina plačilna lista za julij.

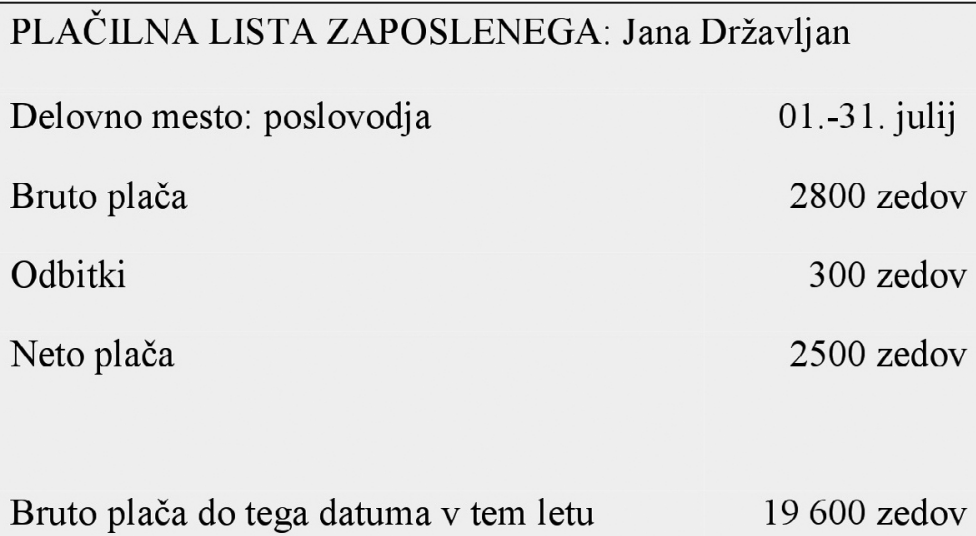

\section{6. vprašanje: PLAČILNA LISTA}

Koliko denarja je Janin delodajalec nakazal na njen bančni račun 3i. julija?
A 300 zedov
B 2500 zedov
C 2800 zedov
D 19600 zedov

\section{PLAČILNA LISTA: TOČKOVANJE 6}

\section{NAMEN VPRAŠANJA:}

Opis: Prepoznati neto znesek na plačilni listi

Vsebina: Denar in transakcije

Proces: Prepoznavanje finančnih podatkov

Kontekst: Izobraževalni in delovni

\section{Pravilen odgovor}

Koda I: $\quad$ B. 2500 zedov 
Nepravilen odgovor

Koda o: $\quad$ Drugi odgovori

Koda 9: $\quad$ Ni odgovora

V predraziskavi PISA 2012 je na to vprašanje pravilno odgovorilo le približno $50 \%$ dijakov iz vseh sodelujočih držav. 


\section{NAPAKA BANKE}

Davidova banka je Zedbanka. David prejme tole elektronsko sporočilo.

\section{Spoštovani komitent Zedbanke!}

Na strežniku Zedbanke je prišlo do napake in vaši prijavni podatki za spletni dostop so izgubljeni.

To pomeni, da nimate dostopa do spletne banke.

Predvsem pa vaš račun ni več varen.

Prosimo, da kliknete na spodnjo povezavo in sledite navodilom za ponovno vzpostavitev dostopa. Prosili vas bomo, da navedete svoje podatke za poslovanje s spletno banko.

\section{https://Zedbanka.com/ zedbanka}

\section{7. vprašanje: NAPAKA BANKE}

Kateri od teh predlogov bi bil dober nasvet za Davida?

Pri vsakem predlogu obkroži “Da” ali "Ne”.

\begin{tabular}{|l|l|}
\hline Predlog & Je ta predlog dober nasvet za Davida? \\
\hline $\begin{array}{l}\text { Naj odgovori na elektronsko sporočilo in navede svoje podatke za poslovanje s sple- } \\
\text { tno banko. }\end{array}$ & $\mathrm{Da} / \mathrm{Ne}$ \\
\hline Naj odgovori na elektronsko sporočilo in prosi za več podatkov. & $\mathrm{Da} / \mathrm{Ne}$ \\
\hline Naj pokliče v svojo banko in se pozanima o elektronskem sporočilu. & $\mathrm{Da} / \mathrm{Ne}$ \\
\hline $\begin{array}{l}\text { Če je povezava enaka kot spletni naslov njegove banke, naj klikne na povezavo in sle- } \\
\text { di navodilom. }\end{array}$ & $\mathrm{Da} / \mathrm{Ne}$ \\
\hline
\end{tabular}


NAPAKA BANKE: TOČKOVANJE 7

\section{NAMEN VPRAŠANJA:}

Opis: Ustrezno se odzvati na elektronsko sporočilo, ki lahko vsebuje finančno potegavščino

Vsebina: Finančni zemljevid

Proces: Vrednotenje finančnih vprašanj

Kontekst: Družbeni

Pravilen odgovor

Koda I: $\quad$ Stirje pravilni odgovori: $\mathrm{Ne}, \mathrm{Ne}, \mathrm{Da}, \mathrm{Ne}$ v tem vrstnem redu.

Nepravilen odgovor

Koda o: $\quad$ Manj kot štirje pravilni odgovori.

Koda 9: $\quad$ Ni odgovora.

V predraziskavi PISA 2012 je na to vprašanje pravilno odgovorilo le približno $40 \%$ dijakov iz vseh sodelujočih držav. 
NOVA BANČNA KARTICA

Liza živi v Zedlandiji. Dobi novo bančno kartico.

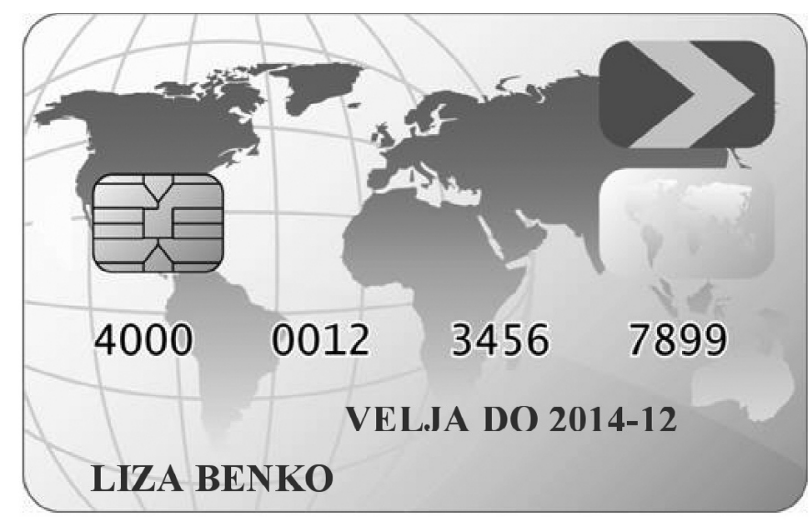

8. vprašanje: NOVA BANČNA KARTICA

Naslednji dan prejme Liza osebno identifikacijsko številko (PIN kodo) za svojo bančno kartico.

Kaj naj Liza stori s PIN kodo?
A PIN kodo naj zapiše na listek in ga spravi v denarnico.
B PIN kodo naj pove svojim prijateljem.
C PIN kodo naj zapiše na hrbtno stran kartice.
D PIN kodo naj si zapomni. 
NOVA BANČNA KARTICA: TOČKOVANJE 8

\section{NAMEN VPRAŠANJA:}

Opis: Prepoznati pravilen način ravnanja s PIN kodo kreditne kartice

Vsebina: Tveganje in dobiček

Proces: Vrednotenje finančnih vprašanj

Kontekst: Osebni

Pravilen odgovor

Kodar: $\quad$ D. $\quad$ PIN kodo naj si zapomni.

Nepravilen odgovor

Koda o: $\quad$ Drugi odgovori.

Koda 9: $\quad$ Ni odgovora.

V predraziskavi PISA 2012 je na to vprašanje pravilno odgovorilo več kot $90 \%$ dijakov iz vseh sodelujočih držav. 


\section{DELNICE}

Spodnji graf prikazuje ceno delnice podjetja Bogatin v 12-mesečnem obdobju.

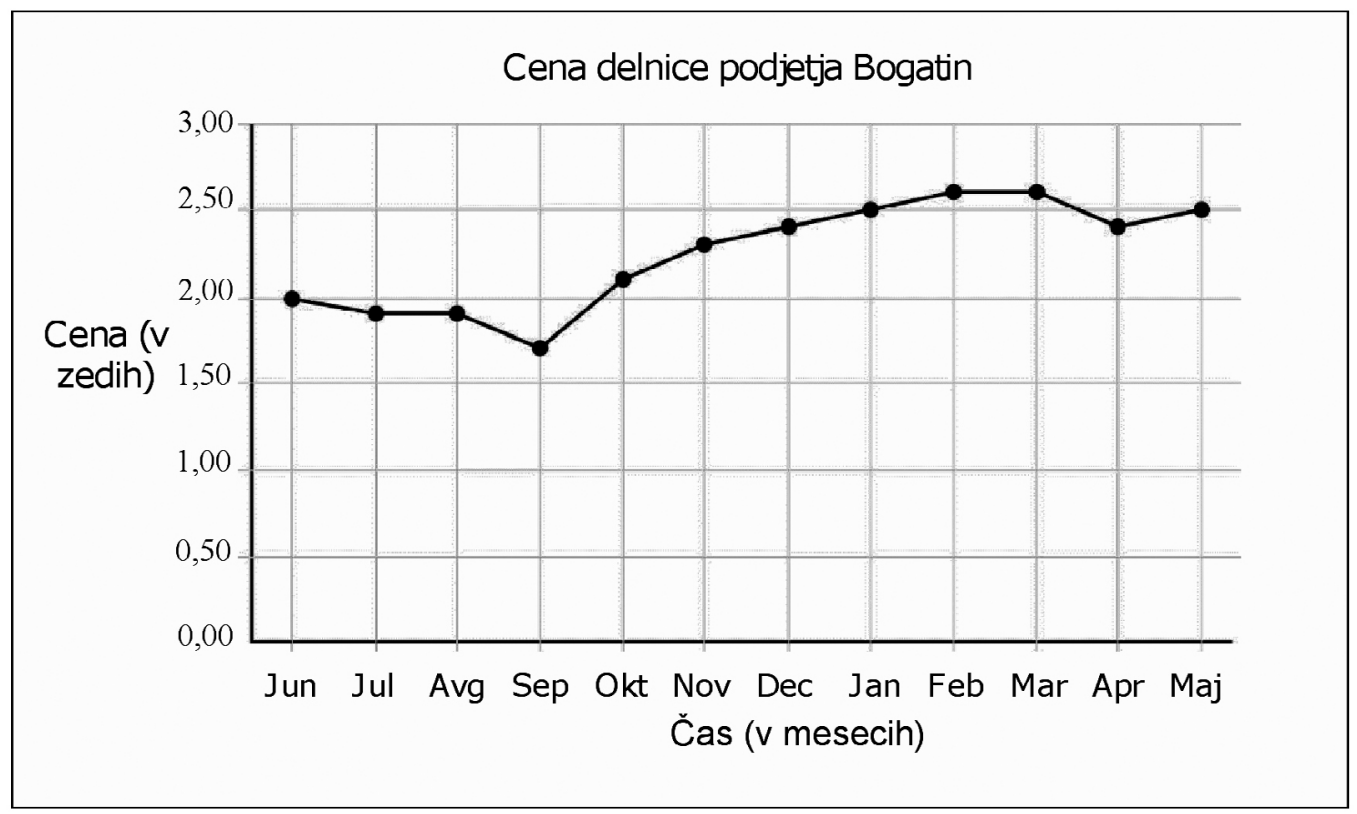

9. vprašanje: DELNICE

Katere trditve o grafu držijo?

Pri vsaki trditvi obkroži "Drži” ali "Ne drži”.

\begin{tabular}{|l|c|}
\hline \multicolumn{1}{|c|}{ Trditev } & Ali ta trditev drži ali ne drži? \\
\hline $\begin{array}{l}\text { Najboljši mesec za nakup delnic je bil } \\
\text { september. }\end{array}$ & Drži / Ne drži \\
\hline $\begin{array}{l}\text { Cena delnice se je med letom povečala } \\
\text { za približno } 50 \% .\end{array}$ & Drži / Ne drži \\
\hline
\end{tabular}




\section{DELNICE: TOČKOVANJE 9}

\section{NAMEN VPRAŠANJA}

Opis: Interpretirati graf, ki prikazuje ceno delnice podjetja v I 2-mesečnem obdobju Vsebina: Tveganje in dobiček

Proces: Razčlenjevanje podatkov znotraj finančnega konteksta

Kontekst: Osebni

Pravilen odgovor

Koda I: $\quad$ Oba pravilna odgovora: Drži, Ne drži, v tem vrstnem redu.

Nepravilen odgovor

Koda o: $\quad$ Manj kot dva pravilna odgovora.

Koda 9: $\quad$ Ni odgovora.

V predraziskavi PISA 2012 je na to vprašanje pravilno odgovorilo približno $50 \%$ dijakov iz vseh sodelujočih držav. 


\section{ZAVAROVANJE MOTORNEGA KOLESA}

Lani je bilo Simonovo motorno kolo zavarovano pri zavarovalnici PRAVA ZAVAROVALNICA.

Zavarovalna polica je krila škodo na motornem kolesu v primeru nesreče in kraje motornega kolesa.

Io. vprašanje: ZAVAROVANJE MOTORNEGA KOLESA

Simon namerava letos podaljšati zavarovanje pri PRAVI ZAVAROVALNICI, vendar se je od lani v Simonovem življenju spremenilo več dejavnikov.

Kako utegne vsak od dejavnikov v tabeli vplivati na strošek Simonovega letošnjega zavarovanja za motorno kolo?

Pri vsakem dejavniku obkroži "Poveča strošek”, “Zmanjša strošek” ali "Ne vpliva na strošek".

\begin{tabular}{|l|c|}
\hline \multicolumn{1}{|c|}{ Dejavnik } & $\begin{array}{c}\text { Kako utegne ta dejavnik vplivati na } \\
\text { strošek Simonovega zavarovanja? }\end{array}$ \\
\hline $\begin{array}{l}\text { Simon je svoje staro motorno kolo zamenjal za } \\
\text { veliko močnejše motorno kolo. }\end{array}$ & $\begin{array}{c}\text { Poveča strošek / Zmanjša strošek/ } \\
\text { Ne vpliva na strošek }\end{array}$ \\
\hline Simon je motor prebarval z drugačno bravo. & $\begin{array}{c}\text { Poveča strošek / Zmanjša strošek / } \\
\text { Ne vpliva na strošek }\end{array}$ \\
\hline Simon je lani povzročil dve prometni nesreči. & $\begin{array}{c}\text { Poveča strošek / Zmanjša strošek / } \\
\text { Ne vpliva na strošek }\end{array}$ \\
\hline
\end{tabular}


ZAVAROVANJE MOTORNEGA KOLESA: TOČKOVANJE ı

\section{NAMEN VPRAŠANJA:}

Opis: Prepoznati dejavnike, ki vplivajo na zavarovalno premijo motornega kolesa Vsebina: Tveganje in dobiček

Proces: Razčlenjevanje podatkov znotraj finančnega konteksta

Kontekst: Osebni

Pravilen odgovor

Koda I: $\quad$ Trije pravilni odgovori: Poveča strošek, Ne vpliva na strošek, Poveča stro šek, v tem vrstnem redu.

Nepravilen odgovor

Koda o: $\quad$ Manj kot trije pravilni odgovori.

Koda 9: $\quad$ Ni odgovora.

V predraziskavi PISA 2012 je na to vprašanje pravilno odgovorilo približno $50 \%$ dijakov iz vseh sodelujočih držav. 



\section{Povzetek}

V pričujoči publikaciji predstavljamo izhodišča merjenja finančne pismenosti v raziskavi PISA 20I2, s primeri nalog, ki so bili uporabljeni v predraziskavi omenjene študije. Na začetku na kratko predstavljamo organizacijske značilnosti raziskave na mednarodni in nacionalni ravni ter vzroke za vse večje zanimanje mednarodnih organizacij za ugotavljanje finančne pismenosti mladih. V nadaljevanju podrobneje predstavljamo strokovna izhodišča merjenja finančne pismenosti, na podlagi katerih so oblikovane naloge. Podrobneje predstavljamo tri temeljne dimenzije, in sicer vsebino (denar in transakcije, načrtovanje in upravljanje financ, tveganje in dobiček ter finančni zemljevid), kognitivne procese (prepoznavanje finančnih podatkov, razčlenjevanje podatkov znotraj finančnega konteksta, vrednotenje finančnih vprašanj in uporaba finančnega znanja in razumevanja) ter kontekst (izobraževalni in delovni, domači in družinski, osebni in družbeni). V okviru tega poglavja predstavljamo tudi določene nekognitivne dejavnike, ki so prav tako pomembni pri ugotavljanju finančne pismenosti mladih (npr. vedenjski vzorci, odnos do finančnih zadev ipd.). Ker je poglaviten cilj pričujoče publikacije raba le-te pri približevanju uporabe znanja $\mathrm{v}$ konkretnih problemsko zasnovanih situacijah učencem in dijakom, ob koncu navajamo še konkretne naloge, ki so bile s tega področja objavljene s strani organizacije OECD. Naloge zajemajo tako uvodno besedilo kot vprašanja ter kodirno shemo za ugotavljanje pravilnih in napačnih odgovorov. 



\section{Summary}

In this publication, we present the framework for measuring financial literacy in PISA 20I2, with examples of units that were used in the field trial of the study. At the beginning we briefly present the organizational characteristics of research at the international and national levels, as well as the reasons for the growing interest of international organizations to determine the financial literacy of young people. Further, we present the framework of measuring financial literacy, on the basis of which the units are formed. In more detail, we present three basic dimensions, namely the content (money and transactions, planning and managing of finances, risk and reward and financial landscape) cognitive processes (identifying financial information, analyse information in the financial context, evaluate financial issues and apply financial knowledge and understanding) and context (education and work, home and family, individual and social). In the context of this chapter, we also present certain non-cognitive factors that are also important in determining the financial literacy of young people (e.g., behavioural patterns, attitudes towards financial matters, etc.). Because the primary objective of this publication is in showing students how to use their knowledge in concrete, problem-based situations, there are concrete units at the end, which were published by the OECD. Units include stimulus, a question and also a coding guide which will help you determine right and wrong answers. 



\section{Literatura}

Barsky, R. B., Juster, F. T., Kimball, M. S. in Shapiro, M. D. (1997). Preference parameters and behavioural heterogeneity: An experimental approach in the health and retirement study. Quarterly Journal of Economics, 11, 537-539.

Bloom, B. S. (ur.). (1956). Taxonomy of educational objectives: The classification of educational goals. Susan Fauer Company Inc.

Holt, C. in Laury, S. (2002). Risk aversion and incentive effects. American Economic Review, 95, 1644-1655.

Huston, S. J. (2010). Measuring financial literacy. The Journal of Consumer Affairs, 44 (2), 296-316.

INFE. (2009a). Financial education programmes in schools: Draft comparative analysis of selected financial education learning frameworks. International Network on Financial Education.

INFE. (2009b). Global message on financial education and the crisis: Draft Comparative Analysis of Selected Financial Education Learning Frameworks. International Network on Financial Education.

Kempson, E., Collard, S. in Moore, N. (2005). Measuring financial capability: An exploratory study. London: Financial Services Authority.

Lusardi, A., Mitchell, O. S. in Curto, V. (2010). Financial literacy among the young. The Journal of Consumer Affairs, 44 (2), 358-380.

OECD. (2005b). Recommendation on principles and good practices for financial education and awareness. OECD: Directorate for Financial and Enterprise Affairs.

OECD. (2008). Improving financial education and awareness on insurance and private pensions. Paris: OECD Publishing. 
OECD. (2009a). Financial literacy and consumer protection: Overlooked aspects of the crisis. Dostopno na spletni strani: //www.financialeducation.org/dataoecd/32/3/43138294. pdf

OECD. (2009b). PIAAC literacy: A conceptual framework. Dostopno na spletni strani: http://www.olis.oecd.org/olis/2009doc.nsf/LinkTo/NT00006EDA/\$FILE/ JT03274637.PDF

OECD. (2010). PISA 2009 framework: Key competencies in reading, mathematics and science. Paris: OECD.

OECD. (2013). PISA 2012 Assessment and Analytical Framework: Mathematics, Reading, Science, Problem Solving and Financial Literacy. Paris: OECD.

Rotter, J. B. (1966). Generalized expectancies for internal versus external control of reinforcement. Psychological Monographs, 80 (1, Whole No. 609).

Štraus, M. (ur.) (2008). Program mednarodne primerjave dosežkov učencev PISA: zbornik prispevkov o metodoloških vidikih raziskave PISA, 1. izd. Ljubljana: Pedagoški inštitut.

Watson, S. (2009). Financial education programmes in schools: comparative analysis of selected financial education learning frameworks (INFE(2009)19). International Network on Financial Education. 


\section{Imensko in stvarno kazalo}

B

Barsky 53

Bloom 43

bralna pismenost 13, 57

Definicija finančne pismenosti 31

dimenzije finančne pismenosti 33, 79

F

finančna pismenosti 13, 21, 22, 23, 24, 25 , $27,28,29,30,31,33,34,39,43,48,49$, $52,53,54,55,56,57,79$

finančno izobraževanje 22, 23, 24, 29, 31, $32,34,35,52$

1

Holt 53

Huston 55

INFE 21, 22, 34, 83, 84
K

Kempson 22, 83

kognitivni procesi 32, 43, 79

Kompetence 13, 29

kontekst finančne pismenosti 49, 50

L

Laury 53

lestvica finančne pismenosti 28, 29

Lusardi 55

M

matematična pismenost $32,55,56$

N

Nacionalni center raziskave PISA 18 naloge iz finančne pismenosti 59 nekognitivni dejavniki finančne pismenosti $29,52,79$

OECD 13, 15, 17, 21, 22, 23, 28, 31, 50, 79, $81,83,84$ 
$\mathrm{P}$

PISA na mednarodni ravni 15,18

PISA na nacionalni ravni 17,18

pravice 6

R

raziskava PISA 13

Rotter 53

S

Štraus 15,84

V

Vprašalnik za dijakinje in dijake 30

vsebina finančne pismenosti 34

W

Watson 34 



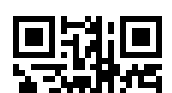 . 吕的}

